Article

\title{
Comprehensive Chemical Profiling in the Ethanol Extract of Pluchea indica Aerial Parts by Liquid Chromatography/Mass Spectrometry Analysis of Its Silica Gel Column Chromatography Fractions
}

\author{
Jingya Ruan ${ }^{1}$, Jiejing Yan ${ }^{2}$, Dandan Zheng ${ }^{1}$, Fan Sun ${ }^{1}$, Jianli Wang ${ }^{2}$, Lifeng Han ${ }^{2}$, \\ Yi Zhang ${ }^{1,2, *}$ and Tao Wang ${ }^{1,2, *}$ \\ 1 Tianjin State Key Laboratory of Modern Chinese Medicine, Tianjin University of Traditional Chinese \\ Medicine, 312 Anshanxi Road, Nankai District, Tianjin 300193, China \\ 2 Tianjin Key Laboratory of TCM Chemistry and Analysis, Institute of Traditional Chinese Medicine, Tianjin \\ University of Traditional Chinese Medicine, 312 Anshanxi Road, Nankai District, Tianjin 300193, China \\ * Correspondence: zhwwxzh@tjutcm.edu.cn (Y.Z.); wangtao@tjutcm.edu.cn (T.W.); \\ Tel./Fax: +86-22-5959-6168 (T.W.)
}

Received: 12 July 2019; Accepted: 29 July 2019; Published: 31 July 2019

check for updates

\begin{abstract}
Pluchea indica Less. is a medicine and food dual-use plant, which belongs to the Pluchea genus, Asteraceae family. Its main constituents are quinic acids, flavonoids, thiophenes, phenolic acids, as well as sesquiterpenes. In order to provide a comprehensive chemical profiling of $P$. indica, an orthogonal chromatography combining reverse-phase chromatography BEHC18 column with a normal-phase chromatography silica column as the separation system and a ESI-Q-Orbitrap MS as the detector in both positive and negative ion modes were used. According to the retention time $\left(t_{R}\right)$ and the exact mass-to-charge ratio $(\mathrm{m} / \mathrm{z}), 67$ compounds were unambiguously identified by comparing to the standard references. Moreover, 47 compounds were tentatively speculated on the basis of the rules of MS/MS fragmentation pattern and chromatographic elution order generalized from the above-mentioned reference standards. Among them, 10 of them were potentially novel.
\end{abstract}

Keywords: Pluchea indica Less.; orthogonal chromatography; normal-phase chromatography silica column separation; reversed-phase liquid chromatography/mass spectrometry analysis; chemical profiling

\section{Introduction}

Pluchea indica Less. belongs to the Asteraceae family, and is a kind of medicine and food dual-use plant which mainly distributes in the tropical and subtropical regions. As a kind of amphibious woody semi-mangrove plant, it not only survives in the intertidal zone and becomes a dominant species on the beach, but also naturally breeds in the terrestrial environment. P. indica plays a significant role in maintaining ecological balance of coastal areas in the southeast of Asia. Its outstanding effect in softening hardness and dissipating binds has been discovered and utilized by people of the Zhuang nationality in Guangxi for several decades [1]. In vitro cytotoxicity test results indicated that the ethanol extract of $P$. indica leaf exhibited wound healing activity, owing to its ability to improve the cell viability of oral mucosal cell line and accelerate wound closure [2], which suggested that $P$. indica has no toxicity. Next, P. indica is not only one of the most famous food ingredients in China [3] but also used as a table salad in Malaysia [4].

Meanwhile, it was also reported that $P$. indica ethanol extract possessed significant inhibitory effects on not only adipocytes lipids and carbohydrate accumulation but also pancreatic lipase activity, 
which provided evidence for its antiobesity activity [5]. Chemical investigation results suggested the main constituents in this plant are quinic acids, thiophenes, flavonoids, and other phenolic acids [6-8]. Among them, quinic acids are the most common dietary polyphenolic compounds, which are widely found in tea, coffee and other foods. It has been reported to exhibit multiple bioactivities such as anti-inflammation and hepatoprotection [4]. What is more, owing to its high content of phenolic compounds, its free radical scavenging activity has been investigated and certified yet, which suggested that $P$. indica displayed antioxidation effect $[9,10]$. Various thiophenes have been considered to be "generally recognized as safe" (GRAS) by the Flavor and Extract Manufacturers Association (FEMA), and re-evaluated to be safe as a kind of food flavor ingredient according to scientific data [11]. What is more, the usage of the phenolic acids in dietary has also been popularized all over the world [12].

The application of $P$. indica in food additives is more and more extensive. However, during the chemical researches in our lab, we found a large amount of pigment existed in the plant made it difficult to accomplish the comprehensive characterization of chemical composition. Meanwhile, the analysis directly acomplished by LC-MS usually limited the characterization fewer than 50 compounds $[13,14]$. A strategy that could improve the chromatographic peak capacity should be considered [15]. As we known, the constituents in P. Indica are varieties, and ideal separation effect is often hardly obtained by conventional reversed-phase chromatography [16]. Then, preliminary fractionation for its crude extracts by normal-phase silica gel column was utilized before reversed-phase chromatography analysis.

According to our previous study $[7,8]$, the main constituents in P. indica are known to be quinic acids, flavonoids, thiophenes, phenolic acids, and sesquiterpenes. And in the process of LC-MS analysis, we found that in the negative ion mode, fragments from $[\mathrm{M}-\mathrm{H}]^{-}$ions could provide more comprehensive information for quinic acids, flavonoids, and phenolic acids, while thiophenes and sesquiterpenes were more inclined to be detected by positive ion mode. Thus, in this study, the ESI-Q-Orbitrap MS was used as the detector in both positive and negative ion modes.

This paper aimed to use a LC-MS analysis method by an orthogonal chromatography (OC) integrating reversed-phase chromatography BEHC18 column with normal-phase chromatography silica column to achieve the characterization and identification of $P$. indica comprehensively. Six fractions of $95 \%$ eluates of the aerial parts of $P$. indica (PIE1-PIE6) were subsequently analyzed by LC-MS on an ESI-Q-Orbitrap MS in both negative and positive ion modes. According to the retention time $\left(t_{R}\right)$ and the exact mass-to-charge ratio $(\mathrm{m} / \mathrm{z}), 67$ compounds were unambiguously identified by comparing to the standard references. Meanwhile, the rules of MS/MS fragmentation pattern and chromatographic elution order have been generalized by using the reference standards, 47 compounds were tentatively speculated, and 10 of them were potential new ones.

\section{Experimental}

\subsection{Materials}

The aerial parts of $P$. indica were collected from Hepu City, Guangxi Province, China, and identified by Dr. Songji Wei (Zhuang Medical College of Guangxi University of Chinese Medicine, Nanning, China). The voucher specimen was deposited at the institute of traditional Chinese Medicine of Tianjin University of TCM.

Sixty-seven compounds, including 20 quinic acids (Figure S1), 19 phenolic acids (Figure S2), 4 thiophenes (Figure S3), 13 flavonoids (Figure S4), and 11 others (Figure S5), were used for reference standards. Their purities were $>98 \%$. Among them, 60 (listed following) were prepared by ourselves, and 7 were purchased.

Among the 20 quinic acids, neochlorogenic acid (5-caffeoylquinic acid), methyl 3-O-caffeoyl quinate, and 1,5-di-O-caffeoyl quinic acid were purchased from Must Company (Chengdu, China); and 17 of them, chlorogenic acid (3-caffeoylquinic acid), 4-caffeoylquinic acid, 1,3-di-O-caffeoyl quinic acid, 1,4-di-O-caffeoyl quinic acid, 3,4-di-O-caffeoyl quinic acid, 3,5-di-O-caffeoyl quinic acid, 4,5-di-O-caffeoyl quinic acid, methyl 3,4-di-O-caffeoyl quinate, methyl 3,5-di-O-caffeoyl quinate, 
methyl 4,5-di-O-caffeoyl quinate, ethyl 3,4-di-O-caffeoyl quinate, ethyl 3,5-di-O-caffeoyl quinate, 1,3,4-tri-O-caffeoyl quinic acid, 1,3,5-tri-O-caffeoyl quinic acid, 3,4,5-tri-O-caffeoyl quinic acid, methyl 3,4,5-tri-O-caffeoyl quinate, and 1,3,4,5-tetra-O-caffeoyl quinic acid were isolated from the aerial parts of $P$. indica and Chrysanthemum morifolium [17].

The phenolic acids, 3,4-dihydroxy benzoic acid, 3-methoxy-4-hydroxybenzoic acid, $p$-hydroxyben zoic acid, and trans-ferulic acid were purchased from Must Company (Chengdu, China). Other 15 ones, 3,4-dihydroxy benzaldehyde, vanillin, 3,4-dihydroxy-5-methoxybenzaldehyde, syringicaldehyde, dibutylphthalate, ethyl caffeate, 2,3-dihydroxy-1-(4-hydroxy-3-methoxyphenyl)-propan-1-one, trans-coniferyl aldehyde, esculetin, threo-2,3-bis(4-hydroxy-3-methoxyphenyl)-3-ethoxypropan-1-ol, erythro-2,3-bis-(4-hydroxy-3-methoxyphenyl)-3-ethoxypropan-1-ol, (+)-isolariciresinol, (-)-(7S,7'S, $\left.8 R, 8^{\prime} R\right)-4,4^{\prime}$-dihydroxy-3,3',5,5'-pentamethoxy-7,9':7',9-diepoxylignane, (+)-9'-isovaleryllariciresinol, and trans-caffeic acid were obtained from the aerial parts of P. indica [7], C. morifolium [18], D. hypoglauca, and L. japonicas.

The thiophenes, (3"R)-pluthiophenol, (3"R)-pluthiophenol-4"-acetate, 3"-ethoxyl-(3"S)pluthiophenol, and 3"-ethoxyl-(3"S)-pluthiophenol-4"-acetate (Figure S3) were isolated from the aerial parts of $P$. indica [7].

Thirteen flavonoids (Figure S4) including quercetin, quercetin-3-O- $\beta$-D-glucopyranoside, quercetin-3-O- $\beta$-D-galactopyranoside, isorhamnetin, 5,6,4'-trihydroxy-3,7-dimethoxyflavone, centaureidin, chrysosplenol $C$, casticin, cynaroside, luteolin, kaempferol 3-O- $\beta$-D-glucopyranoside (astragalin), 5,7,3',4'-tetrahydroxy-3-methoxyflavonol-3'-O- $\beta$-D-glucopyranoside, and kaempferol were isolated from the aerial parts of $P$. indica [8], C. morifolium [17], and L. leontopodioides by us.

Eleven other compounds (Figure S5), caryolane-1,9 $\beta$-diol, (8R,9R)-isocaryolane-8,9-diol, clovane-2 $\alpha, 9 \beta$-diol, valenc-1(10)-ene-8,11-diol, fraxinellone, stigmasterol, methyl 10-oxoundecanoate, triethyl citrate, 9,12,13-trihydroxyoctadeca-10(E),15(Z)-dienoic acid, and pinellic acid together with adenosine were obtained from $P$. indica aerial parts [7].

HPLC grade Acetonitrile (Thermo-fisher, Waltham, MA, USA) and ultrapure water prepared with a Milli-Q purification system (Merck Millipore, Darmstadt, Hesse-Darmstadt, Germany) were used for LC-MS analysis. Analytical-grade ethanol $(\mathrm{EtOH})$, chloroform $\left(\mathrm{CHCl}_{3}\right)$, and methanol $(\mathrm{MeOH})$ (Haiguang Chemical Reagent Factory, Tianjin, China), as well as silica gel (48-75 $\mu \mathrm{m}$, Haiyang Chemical Reagent Factory, Qingdao, China) were used for the preparation of P. indica 70\% EtOH extract (PI) and silica gel fractionation of $95 \% \mathrm{EtOH}$ eluate (PIEs) test solutions.

\subsection{Sample Preparation}

\subsubsection{Preparation of Standard Solutions}

Standard test solutions of above mentioned standard references were prepared in $\mathrm{MeOH}$ at a final concentration of $\sim 100 \mathrm{ng} / \mathrm{mL}$. All stock solutions were stored at $4{ }^{\circ} \mathrm{C}$ in darkness and brought to room temperature before use.

\subsubsection{Preparation of $P$. indica $70 \%$ EtOH Extract Test Solutions}

An aliquot of $100 \mathrm{~g}$ dried aerial parts of $P$. indica was extracted under reflux in 800,600, and 600 $\mathrm{mL} 70 \%$ ethanol $(v / v)$ for 3,2 , and $2 \mathrm{~h}$, respectively. The combined extracts were filtered with $0.22 \mu \mathrm{m}$ microporous membrane to obtained PI stock solutions. PI stock solutions were stored at $4{ }^{\circ} \mathrm{C}$ in darkness and brought to room temperature before use.

\subsubsection{Preparation of Silica Gel Fractionation of $95 \%$ EtOH Eluate of P. indica Test Solutions}

The above-mentioned PI stock solutions were evaporated to dryness under reduced pressure to obtain PI extract $(20.55 \mathrm{~g})$. The PI extract was dissolved in $800 \mathrm{~mL}$ of water and separated by D101 macroporous adsorption resin column $\left(\mathrm{H}_{2} \mathrm{O} \rightarrow 95 \% \mathrm{EtOH}\right)$ to obtain $\mathrm{H}_{2} \mathrm{O}$ eluate $(15.45 \mathrm{~g})$ and $95 \%$ $\mathrm{EtOH}$ eluate (PIE, $5.0 \mathrm{~g})$, respectively. PIE (5.0 g) were subjected to normal-phase silica gel (50.0 g) 
column $\left(\mathrm{CHCl}_{3}-\mathrm{MeOH}\left(100: 1 \rightarrow\right.\right.$ 100:5, v/v) $\rightarrow \mathrm{CHCl}_{3}-\mathrm{MeOH}-\mathrm{H}_{2} \mathrm{O}(10: 3: 1 \rightarrow$ 7:3:1 $\rightarrow$ 6:4:1 $\rightarrow$ 5:5:1, $v / v / v$, lower layer) $\rightarrow \mathrm{MeOH}$ ), six fractions (PIE1-PIE6) were obtained. PIE1-PIE6 were evaporated to dryness under reduced pressure, and then dissolved with $\mathrm{MeOH}$ to get six test stock solutions at a final concentration of $10 \mathrm{mg} / \mathrm{mL}$. PIEs stock solutions were stored at $4{ }^{\circ} \mathrm{C}$ in darkness and brought to room temperature before use.

\subsection{UHPLC}

A Thermo UltiMate 3000 UHPLC instrument (Thermo, Waltham, MA, USA) equipped with a quaternary pump and an autosampler were used to accomplish the analysis. Samples were separated on a Waters ACQUITY UPLC®BEH C18 $(2.1 \times 100 \mathrm{~mm}, 1.7 \mu \mathrm{m}$, Milford, MA, USA $)$ using a mobile phase composed of $\mathrm{H}_{2} \mathrm{O}(\mathrm{A})$ and $\mathrm{CH}_{3} \mathrm{CN}$ with $0.1 \% \mathrm{CH}_{3} \mathrm{COOH}(\mathrm{B})$ in the following gradient program; 0-4 min, 1-4\% B; 4-18 min, 4\% B; 18-20 min, 4-13\% B; 20-24 min, 13\% B; 24-35 min, 13-15\% B; 35-37 min, 15-24\% B; 37-45 min, 24-30\% B; 45-46 min, 30-55\% B; 46-52 min, 55\% B; 52-53 min, 55-95\% B; 53-58 min, 95\% B. An equilibration of $3 \mathrm{~min}$ was used between successive injections. The flow rate was $0.4 \mathrm{~mL} / \mathrm{min}$, and column temperature was $35^{\circ} \mathrm{C}$. An aliquot of $3 \mu \mathrm{L}$ of each sample was injected for analysis.

\subsection{ESI-Q-Orbitrap MS and Automatic Components Extraction}

For tandem mass spectrometry analysis, a Thermo ESI-Q-Orbitrap MS mass spectrometer was connected to the UltiMate 3000 UHPLC instrument via ESI interface. Ultrahigh purity nitrogen $\left(\mathrm{N}_{2}\right)$ was used as the collision gas and the sheath/auxiliary gas. The ESI source parameters were set as follows: ion spray voltage $3.2 \mathrm{kV}$, capillary temperature $350{ }^{\circ} \mathrm{C}$, ion source heater temperature $300{ }^{\circ} \mathrm{C}$, sheath gas $\left(\mathrm{N}_{2}\right) 40$ arbitrary units, auxiliary gas $\left(\mathrm{N}_{2}\right) 10$ arbitrary units, and a normalized collision energy (NCE) of $35 \mathrm{~V}$ was used. The Orbitrap analyzer scanned the mass range from $m / z 100$ to 1500. Monitoring time was 0-58 min. Detection was obtained by full mass-dd mass mode. The MS data were recorded in both profile and centroid formats. Data recording and processing were performed using the Xcalibur 4.0 software (Thermo Fisher Scientific, Inc., Waltham, MA, USA). The accuracy error threshold was fixed at 5 ppm.

Software-aided, automatic background subtraction and components extraction techniques were used to generate a peak list containing all the components profiled from the aerial part of $P$. indica. Sieve v2.2 SP2 (Thermo Fisher Scientific) was used for the automatic components extraction: time range: 1-58 min; BP minimum count: 10,000; BP minimum scans: 5; Background SN: 3; MZ Step: 10; and Frame, $>1$.

\section{Results and Discussion}

OC-MS technology integrated the large peak capacity of OC with the high detected sensitivity of MS, which could accomplish more comprehensive chemical profiling. Through comparing the separation effects of four kinds of high performance liquid chromatography columns (HSS C18, T3, CSH FP, and BEH C18 columns) with different separation mechanisms for PI, BEH C18 column was found to have better separation ability for most of the peaks in PI (Figure S6). Then, it was chosen to carry out the composition analysis of $P$. indica. The comprehensive and accurate chemical composition profiling of $P$. indica was further accomplished by the OC-MS combined normal-phase silica gel column with reverse-phase BEH C18 column (Figures 1 and 2). As a result, the peak capacity and detection sensitivity were improved significantly, which is discussed in detail as follows. 

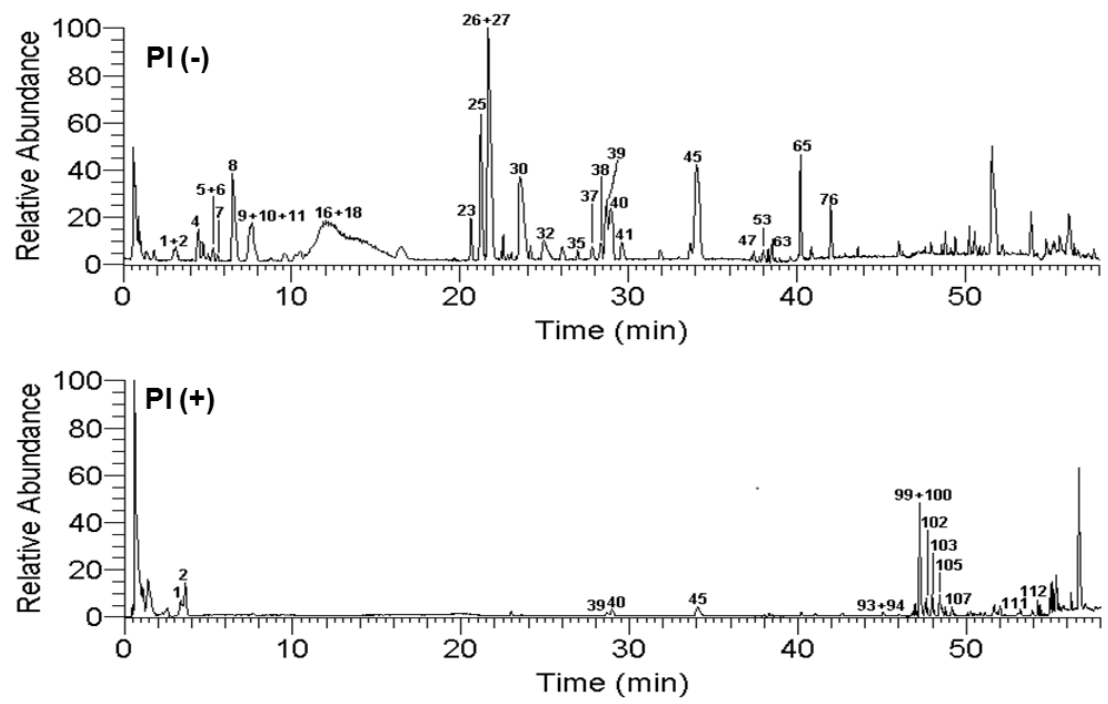

Figure 1. Base peak chromatograms of $P$. indica $70 \%$ EtOH extract on BEHC18 column in negative and positive mode.
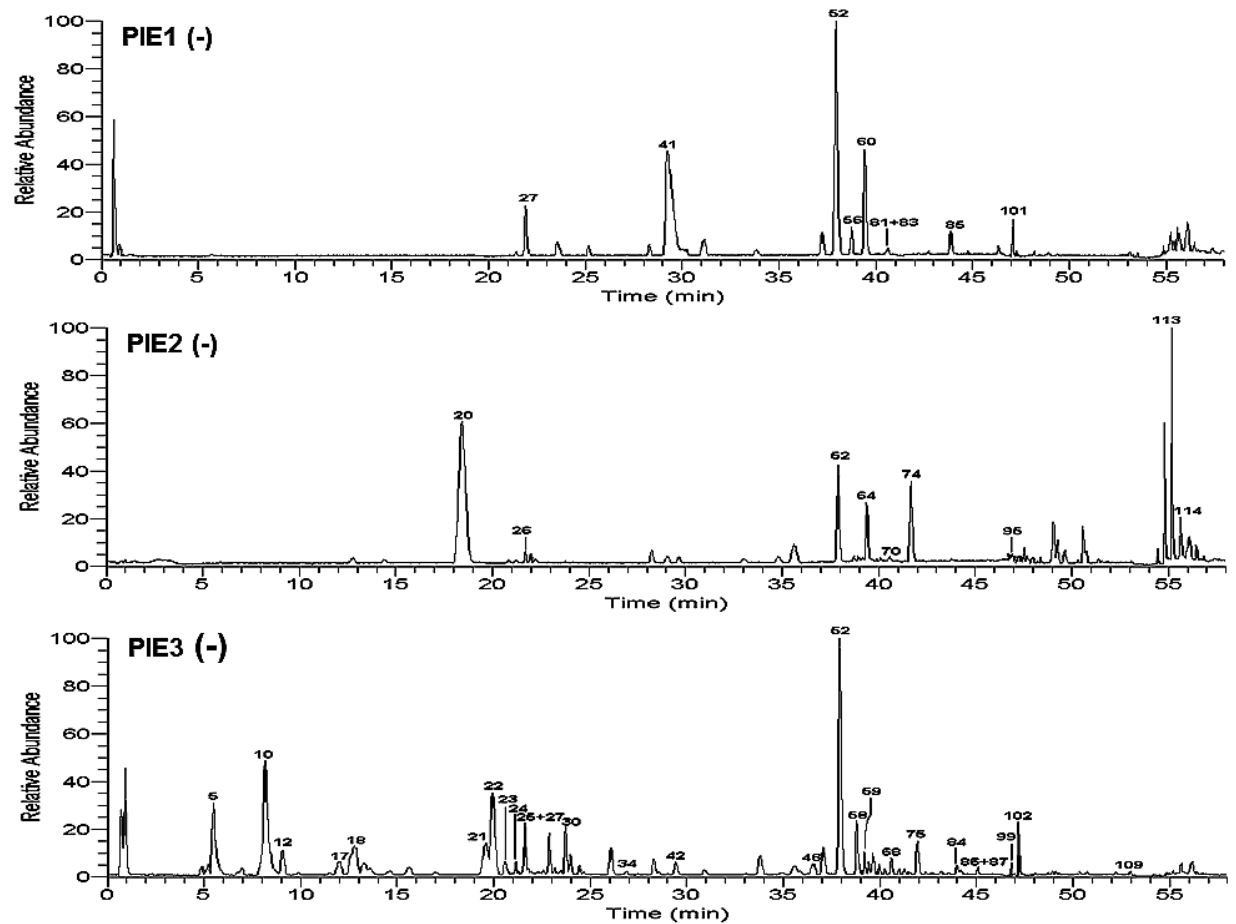

Figure 2. Cont. 

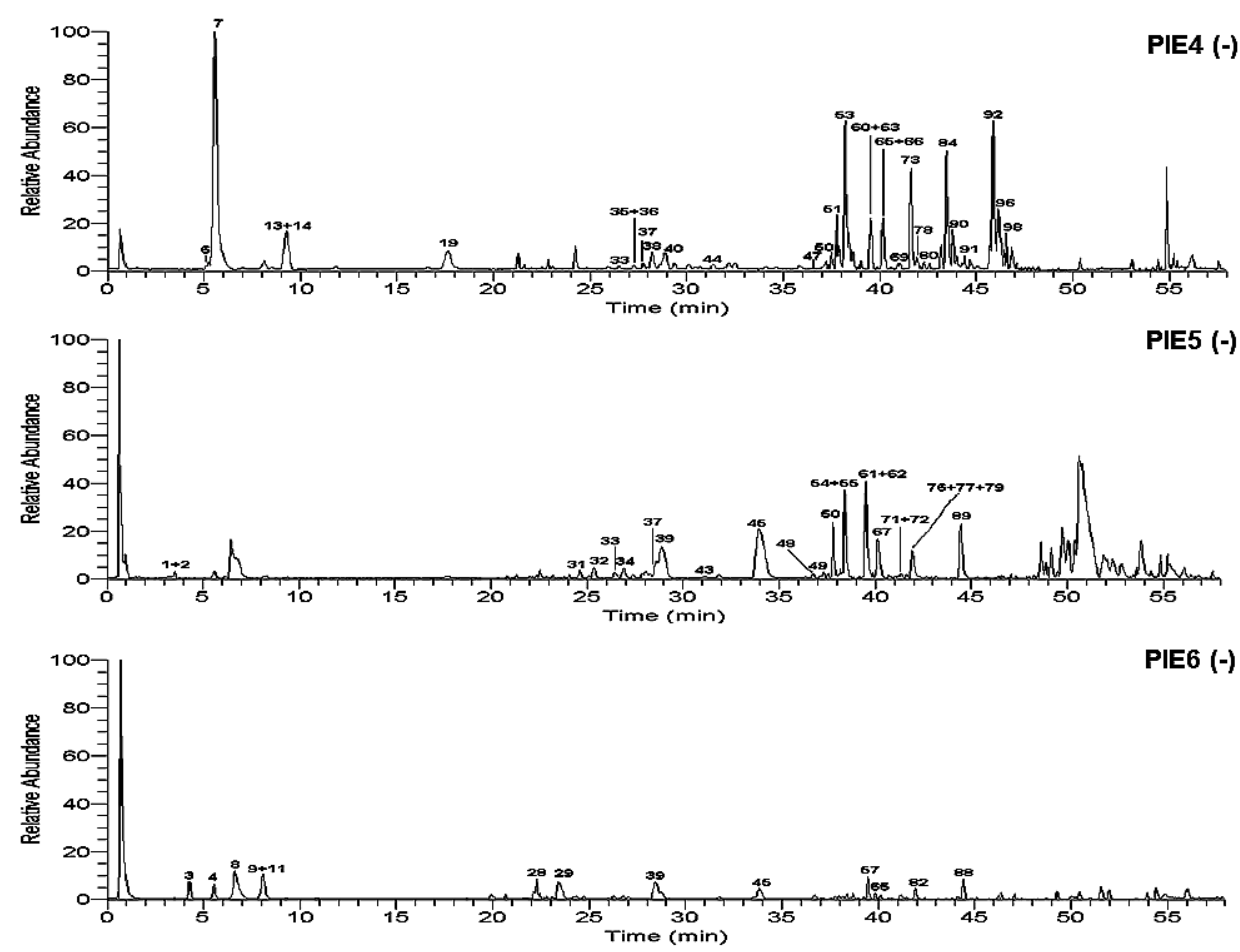

Figure 2. Base peak chromatograms of silica gel fractionation of $95 \% \mathrm{EtOH}$ eluate of $P$. indica on BEHC18 column in negative mode.

3.1. Superiority of OC-MS than Directly LC-MS in the Chemical Composition Profiling of P. indica $70 \%$ EtOH Extract

\subsubsection{Increasing of the Peak Capacity by OC-MS Determination}

OC-MS, combing the advantages of the large peak capacity of OC and high sensitivity of mass spectrometry, had a wide range of applications, especially in the systematic chemical composition characterization of Traditional Chinese Medicine [15].

The sieve statistical results indicated that OC-MS possessed much more peaks than directly LC-MS (PI: 234 peaks detected; PIEs: 735 peaks detected).

Taking the ion peak at $40.13 \mathrm{~min}$ as an example, when extracting it from the total ion chromatogram of PI, only the ion at $\mathrm{m} / \mathrm{z} 677.15147$ corresponding to 3,4,5-tricaffeoyl quinic acid could be observed obviously (Figure S7). However, two ion peaks of belonging to 3,5-dicaffeylquinine ethyl acetate $(\mathrm{m} / \mathrm{z}$ 543.15136) and 3,4,5-tricaffeoylquinic acid $(\mathrm{m} / \mathrm{z}$ 677.15126) (Figure S8) were extracted from the ion peak at $40.13 \mathrm{~min}$ of PIE4. And both of them appeared with extremely strong intensity. This result suggested that OC-MS technique could increase peak capacity of the chromatography greatly.

\subsubsection{Increasing of the Detection Sensitivity by OC-MS Determination}

Ion peaks of $m / z 677.15119$ were extracted from the total ion chromatogram of PI and PIE6 (Figure S9). It was found that the peak area ratios of 1,3,5-tricaffeoyl quinic acid (36.63 $\mathrm{min}), 1,3,4$-tricaffeoylquinic acid (38.13 $\mathrm{min})$, and 1,4,5-tricaffeoylquinic acid (39.86 $\mathrm{min})$ to 3,4,5-tricaffeoylquinic acid (40.11 min) in PIE5 $(0.15,0.11$, and 0.09 , respectively) were significantly higher than those in PI $(0.03,0.03$, and 0.01 , respectively). The above-mentioned results indicated that OC-MS technique could improve detection sensitivity. 
3.2. Structural Elucidation of Compounds from Silica Gel Fractionation of $95 \%$ EtOH Eluate of P. indica by OC-MS

\subsubsection{Structural Elucidation of Quinic Acids and Their Derivatives}

Quinic acids and their derivatives are one kind of the most characteristic components in Asteraceae family plants [19-21]. There are four hydroxyl groups substituted at 1-, 3-, 4-, and 5-position, as well as one carboxyl at 1-position of quinic acid, respectively, which means that the quinic acids derivatives can be formed at any one of above mentioned position or functional group theoretically. In fact, 1-, 3-, 4-, and 5-hydroxyl can dehydrate with caffeic acid, ferulic acid, coumaric acid, and 3,4,5-trihydroxycinnamic acid to form acyl-substituted quinic acids. What is more, the 1-carboxyl is easily to form methyl and ethyl esters.

Structural Elucidation of Mono-acyl Substituted Quinic Acids and Their Derivatives

Peaks $4\left(\mathrm{~m} / \mathrm{z} 353.08710[\mathrm{M}-\mathrm{H}]^{-}\right), \mathbf{1 1}\left(\mathrm{m} / \mathrm{z} 353.08716[\mathrm{M}-\mathrm{H}]^{-}\right)$, and $16\left(\mathrm{~m} / \mathrm{z} 353.08699[\mathrm{M}-\mathrm{H}]^{-}\right)$ were unambiguously confirmed to be 5-caffeoylquinic acid (5-CQA), 3-CQA, and 4-CQA, respectively, by comparing to the standard references obtained from $C$. morifolium [17]. As a result, the general MS/MS cleavage pattern of CQAs was summarized, which mainly included ester bond cleavage between caffeoyl and quinic acid groups, quinic acid dehydration, along with caffeoyl decarbonylation. Then, characteristic fragment ions at $m / z 179.03389$ [caffeoyl $-\mathrm{H}^{-}, 161.02332$ [caffeoyl $\left.-\mathrm{H}-\mathrm{H}_{2} \mathrm{O}\right]^{-}$, 135.04406 [caffeoyl $\left.-\mathrm{H}-\mathrm{CO}_{2}\right]^{-}, 133.02841$ [caffeoyl $\left.-\mathrm{H}-\mathrm{H}_{2} \mathrm{O}-\mathrm{CO}\right]^{-}$for caffeoyl group and $\mathrm{m} / \mathrm{z}$ 191.05501 [quinic acid $-\mathrm{H}]^{-}, 173.04445$ [quinic acid $\left.-\mathrm{H}-\mathrm{H}_{2} \mathrm{O}\right]^{-}$for quinic acid group were displayed in their mass spectra (Figure 3).

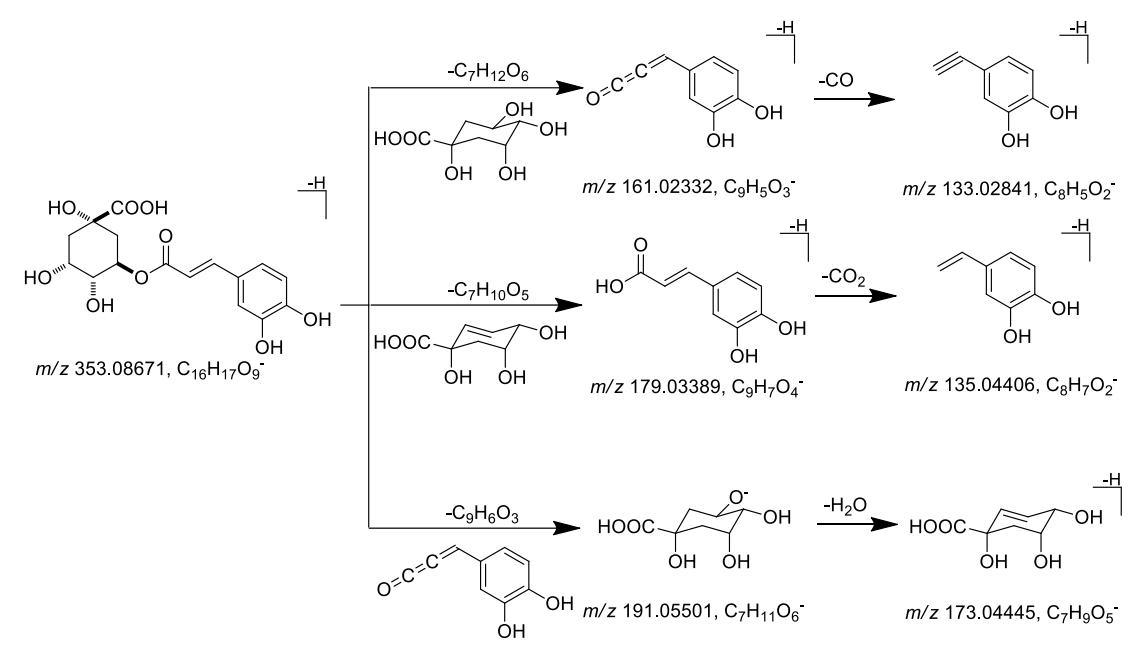

Figure 3. Proposed fragmentation patterns and characteristic ions of caffeoylquinic acid.

Comparing the MS/MS fragmentation characteristics and relative ion abundance of CQAs, it was found that the fragment ion type and ion intensity had a great correlation with the substitution position of caffeoyl group: in the MS/MS spectrum for 3-CQA, the characteristic fragment ion at $\mathrm{m} / \mathrm{z}$ 191.05501 derived from quinic acid aglycone was the base peak; however, the ion peaks at $m / z 179.03389$, $161.02332,135.04406$, and 133.02841 for caffeoyl group and $\mathrm{m} / z 173.04445$ for quinic acid group were very weak; in the MS/MS spectrum for 4-CQA, the ion peaks at $\mathrm{m} / \mathrm{z} 191.05501$ and 173.04445 for quinic acid group and 179.03389 and 135.04406 for caffeoyl group were stronger, and the base peak was $\mathrm{m} / \mathrm{z}$ 173.04445 from quinic acid aglycone; meanwhile, in the MS/MS spectrum for 5-CQA, not only the characteristic fragment ions of $\mathrm{m} / \mathrm{z} 191.05501$ for quinic acid nucleus existed as base peak, but also the strong caffeoyl characterization fragment ions at $\mathrm{m} / z 179.03389$ and 135.04406 displayed (Figure S10). This phenomenon has also been observed in the study of chlorogenic acids in Kuding Tea [22]. This feature might be caused by the axial conformation of 5-caffeoyl group, which made it easy for the 
cleavage of 5-caffeoyl group from the quinic acid nucleus to form relative stable fragmentation ions of both quinic acid and caffeoyl group.

Moreover, the chromatographic elution order [retention time $\left(t_{\mathrm{R}}\right)$ ] of CQAs in the $\mathrm{CH}_{3} \mathrm{CN}-\mathrm{H}_{2} \mathrm{O}$ system was denoted as 5-CQA (peak $4, t_{\mathrm{R}} 4.97 \mathrm{~min}$ ) $<3$-CQA (peak 11, $t_{\mathrm{R}} 8.20 \mathrm{~min}$ ) < 4-CQA (peak 16, $\left.t_{\mathrm{R}} 10.69 \mathrm{~min}\right)$.

According to the reference [23], the substituted group of quinic acid aglycone could also be feruloyl, and coumaroyl except for caffeoyl; mono-feruloyl quinic acid (FQAs) and mono-coumaroyl quinic acid (CoQAs) were also formed. Moreover, the possibility of 3,4,5-trihydroxycinnamoyl substitution (another kind of caffeoyl derivatives) has also been considered, which could form mono-3,4,5-trihydroxycinnamoyl quinic acid (TQAs). The characteristic ions of caffeoyl, feruloyl, coumaroyl, and 3,4,5-trihydroxycinnamoyl were considered to be at $m / z 179.03389\left([\text { caffeoyl }-\mathrm{H}]^{-}\right)$, 193.04954 ([feruloyl - H] $\left.]^{-}\right), 163.03897\left([\text { coumaroyl }-\mathrm{H}]^{-}\right)$, and $195.02880([3,4,5$-trihydroxycinnamoyl $\left.-\mathrm{H}]^{-}\right)$, respectively, which could be used to distinguish the type of substituted group.

In the MS/MS fragmentation spectra of peaks $3\left(\mathrm{~m} / z 369.08246[\mathrm{M}-\mathrm{H}]^{-}\right), 9\left(\mathrm{~m} / z 369.08266[\mathrm{M}-\mathrm{H}]^{-}\right)$, and $15\left(\mathrm{~m} / \mathrm{z} 369.08233[\mathrm{M}-\mathrm{H}]^{-}\right)$(Figure S11), there were noticeable $m / z 195.02880\left(\mathrm{C}_{9} \mathrm{H}_{7} \mathrm{O}_{5}{ }^{-}\right)$ions, which indicated that they were substituted by 3,4,5-trihydroxycinnamoyl group. The base peak of the MS/MS fragmentation spectra for peaks 3, 9, and 15 was $m / z$ 191.05483, 133.02803, and 173.04421, respectively, and there were relatively strong ion at $\mathrm{m} / \mathrm{z} 133.02803$ in that of peak 3 . Thus, based on the above rules of MS/MS cleavage patterns and chromatographic elution order generalized by 5-CQA (peak 4), 3-CQA (peak 11), and 4-CQA (peak 16), they were tentatively deduced to be 5-TQA (peak 3), 3-TQA (peak 9), and 4-TQA (peak 15), respectively. They were all possible new ones. Using the same method, peaks $18\left(\mathrm{~m} / \mathrm{z} 337.09254[\mathrm{M}-\mathrm{H}]^{-}\right)$and $20\left(\mathrm{~m} / \mathrm{z} 337.09268[\mathrm{M}-\mathrm{H}]^{-}\right)$were tentatively identified as 3-CoQA and 4-CoQA, respectively (Figure S12).

Peak $29\left(\mathrm{~m} / \mathrm{z} 367.10270[\mathrm{M}-\mathrm{H}]^{-}\right)$was unambiguously identified as 3-CQM by comparing with reference standard. Though the molecular of peaks $21\left(\mathrm{~m} / z 367.10266[\mathrm{M}-\mathrm{H}]^{-}\right), 22(\mathrm{~m} / z 367.10208$ $\left.[\mathrm{M}-\mathrm{H}]^{-}\right), 24\left(\mathrm{~m} / \mathrm{z} 367.10254[\mathrm{M}-\mathrm{H}]^{-}\right)$, and $28\left(\mathrm{~m} / \mathrm{z} 367.10260[\mathrm{M}-\mathrm{H}]^{-}\right)$were similar with that of peak 29;

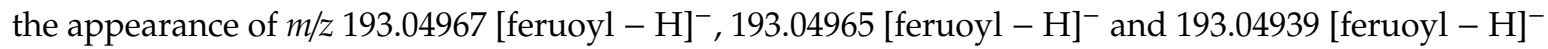
in the MS/MS spectra of peaks 21, 22, and 24, respectively, indicated that these three compounds were substituted by feruoyl group. According to the chromatographic elution order summarized above, peaks 21, 22, and 24 were tentatively identified as 5-FQA, 3-FQA, and 4-FQA, respectively. In the MS/MS spectrum of peak 28, the ions at $m / z 193.04954$ [feruoyl - H] ${ }^{-}$was absent, while $m / z 179.03380$ [caffeoyl $-\mathrm{H}^{-}, 161.02313$ [caffeoyl $-\mathrm{H}-\mathrm{H}_{2} \mathrm{O}^{-}$appeared, then it was deduced to be CQM. According to the chromatographic elution order of CQAs $\left(t_{\mathrm{R}}: 5-\mathrm{CQA}<3-\mathrm{CQA}<4-\mathrm{CQA}\right)$, and combining the occurrence probability of 1-CQM and 5-CQM, peak 28 was tentatively deduced to be 5-CQM. And it was found to be a new compound (Figure S13).

Structural Elucidation of Multi-acyl Substituted Quinic Acids and Their Derivatives

Peaks $\left.35\left(m / z 515.11761[\mathrm{M}-\mathrm{H}]^{-}\right), 37\left(\mathrm{~m} / z 515.11694[\mathrm{M}-\mathrm{H}]^{-}\right), 38(\mathrm{~m} / z \text { 515.11797 [M - H] }]^{-}\right), 39(\mathrm{~m} / \mathrm{z}$ $\left.515.11713[\mathrm{M}-\mathrm{H}]^{-}\right), 40\left(\mathrm{~m} / z 515.11950[\mathrm{M}-\mathrm{H}]^{-}\right)$, and $45\left(\mathrm{~m} / z 515.11523[\mathrm{M}-\mathrm{H}]^{-}\right)$were definitively identified as 1,4-dicaffeoylquinic acid (1,4-diCQA), 1,5-diCQA, 1,3-diCQA, 4,5-diCQA, 3,5-diCQA, and 3,4-diCQA, respectively, by comparing to the standard references obtained from C. morifolium and P. indica. According to the MS/MS spectra of the six diCQAs, the general MS/MS fragmentation pattern diCQAs was summed up as following: the ion peak at $m / z 173.04434\left[\mathrm{M}-\mathrm{H}-2 \mathrm{C}_{9} \mathrm{H}_{6} \mathrm{O}_{3}-\mathrm{H}_{2} \mathrm{O}\right]^{-}$, 173.04420 [M - H - 2 $\left.\mathrm{C}_{9} \mathrm{H}_{6} \mathrm{O}_{3}-\mathrm{H}_{2} \mathrm{O}\right]^{-}$, and $173.04430\left[\mathrm{M}-\mathrm{H}-2 \mathrm{C}_{9} \mathrm{H}_{6} \mathrm{O}_{3}-\mathrm{H}_{2} \mathrm{O}\right]^{-}$derived from quinic acid aglycone was found to be the base peak in the MS/MS spectra of 35 (1,4-diCQA), 39 (4,5-diCQA), and 45 (3,4-diCQA), respectively (Figure S14); the base peak of 37 (1,5-diCQA) was $m / z 135.04356$ $\left[\mathrm{M}-\mathrm{H}-\mathrm{C}_{9} \mathrm{H}_{6} \mathrm{O}_{3}-\mathrm{C}_{7} \mathrm{H}_{10} \mathrm{O}_{5}-\mathrm{CO}_{2}\right]^{-}$for caffeoyl group (Figure S14); however, for 38 (1,3-diCQA) and 40 (3,5-diCQA), $m / z 191.05495\left[\mathrm{M}-\mathrm{H}-2 \mathrm{C}_{9} \mathrm{H}_{6} \mathrm{O}_{3}\right]^{-}$and $191.05480\left[\mathrm{M}-\mathrm{H}-2 \mathrm{C}_{9} \mathrm{H}_{6} \mathrm{O}_{3}\right]^{-}$derived from quinic acid aglycone was the base peak, respectively (Figure S14). The above mentioned rules was 
similar to those of CQAs, which suggested that when C-4 was substituted by caffeoyl $(35,39,45), m / z$ 173.04445 was an indicator ion as its strong intensity (Figure S14).

In addition, the chromatographic elution order of diCQAs in the $\mathrm{CH}_{3} \mathrm{CN}-\mathrm{H}_{2} \mathrm{O}$ system was showed as 1,4-diCQA (peak 35, $t_{\mathrm{R}} 27.11 \mathrm{~min}$ ) $<1$,5-diCQA (peak 37, $t_{\mathrm{R}} 27.99 \mathrm{~min}$ ) $<1,3$-diCQA (peak 38, $t_{\mathrm{R}}$ $28.07 \mathrm{~min}$ ) < 4,5-diCQA (peak 39, $t_{\mathrm{R}} 28.68 \mathrm{~min}$ ) $<3,5$-diCQA (peak 40, $t_{\mathrm{R}} 28.89 \mathrm{~min}$ ) <3,4-diCQA (peak $\left.45, t_{\mathrm{R}} 34.01 \mathrm{~min}\right)$. Meanwhile, comparing with the $t_{\mathrm{R}}$ of CQAs, that of diCQAs was longer significantly. On the other hand, $t_{\mathrm{R}}$ of C-1 substituted diCQAs was shorter than that of other diCQAs.

Using the above-mentioned rules, the peaks $46\left(\mathrm{~m} / \mathrm{z} 529.13623[\mathrm{M}-\mathrm{H}]^{-}\right), 48(\mathrm{~m} / \mathrm{z} 529.13515$ $\left.[\mathrm{M}-\mathrm{H}]^{-}\right), 49\left(\mathrm{~m} / \mathrm{z} 529.13452[\mathrm{M}-\mathrm{H}]^{-}\right)$were tentatively deduced. The research process was described as following: in the MS/MS spectra of peaks 46, 48, and 49, there were $m / z 193.04970\left[\mathrm{M}-\mathrm{H}-\mathrm{C}_{16} \mathrm{H}_{16} \mathrm{O}_{8}\right]^{-}$, $193.04991\left[\mathrm{M}-\mathrm{H}-\mathrm{C}_{16} \mathrm{H}_{16} \mathrm{O}_{8}\right]^{-}$, and $193.04980\left[\mathrm{M}-\mathrm{H}-\mathrm{C}_{16} \mathrm{H}_{16} \mathrm{O}_{8}\right]^{-}$for 46, 48, and 49, respectively, along with $134.03615\left[\mathrm{M}-\mathrm{H}-\mathrm{C}_{16} \mathrm{H}_{16} \mathrm{O}_{8}-\mathrm{CH}_{3}-\mathrm{CO}_{2}\right]^{-}, 134.03642\left[\mathrm{M}-\mathrm{H}-\mathrm{C}_{16} \mathrm{H}_{16} \mathrm{O}_{8}-\mathrm{CH}_{3}-\right.$ $\left.\mathrm{CO}_{2}\right]^{-}$, and $134.03607\left[\mathrm{M}-\mathrm{H}-\mathrm{C}_{16} \mathrm{H}_{16} \mathrm{O}_{8}-\mathrm{CH}_{3}-\mathrm{CO}_{2}\right]^{-}$for 46, 48, and 49, respectively (characteristic fragment ions for feruloyl group); as well as $m / z 179.03404\left[\mathrm{M}-\mathrm{H}-\mathrm{C}_{17} \mathrm{H}_{18} \mathrm{O}_{8}\right]^{-}, 179.03429[\mathrm{M}-\mathrm{H}-$ $\left.\mathrm{C}_{17} \mathrm{H}_{18} \mathrm{O}_{8}\right]^{-}$, and $179.03400\left[\mathrm{M}-\mathrm{H}-\mathrm{C}_{17} \mathrm{H}_{18} \mathrm{O}_{8}\right]^{-}$, respectively (characteristic fragment ion for caffeoyl group). Therefore, it was presumed that they were CFQAs substituted by a mono-caffeoyl group and a mono-feruloyl group in different positions of quinic acid aglycone at the same time. As the characteristic fragment ion $\mathrm{m} / \mathrm{z} 173.04445$ was not the base peak ion of their MS/MS spectra, the possibility that caffeoyl or feruloyl linked at C-4 of the quinic acid aglycone was excluded. Combining the chromatographic elution order of diCQAs in the $\mathrm{CH}_{3} \mathrm{CN}-\mathrm{H}_{2} \mathrm{O}$ system summarized above, peaks 46, 48, and 49 were deduced to be 1-C-5-FQA/5-C-1-FQA, 1-C-3-FQA/3-C-1-FQA, and 3-C-5-FQA/5-C-3-FQA, respectively. Moreover, in the dominant conformation of the six-membered ring quinic acid aglycone, both 1- and $5-\mathrm{OH}$ were at the axial bond, the substitution on $\mathrm{C}-1$ and 5 were more likely to cleavage from the aglycone in the mass spectrometry than they were at other positions. Thus according to the stability of fragment ions (relative abundance) after substituent cleavage, the substitution position could be preliminary identified. For example, in peak 49, the fragment ion intensity of $m / z 367.10309$ [M - H $\left.\mathrm{C}_{9} \mathrm{H}_{6} \mathrm{O}_{3}\right]^{-}$(derived from the cleavage of one caffeoyl group $162 \mathrm{Da}$ ) was high, which suggested that the caffeoyl group was linked to the C-5 of quinic acid aglycone. Therefore, it was finally determined that the peak 49 was 3-feruloyl-5-caffeoyl-quinic acid. Using a similar method, peak 48 was speculated to be 1-caffeoyl-3-feruloyl-quinic acid (Figure S15).

Peaks $51\left(\mathrm{~m} / z 529.13409[\mathrm{M}-\mathrm{H}]^{-}\right), 55\left(\mathrm{~m} / z 529.13403[\mathrm{M}-\mathrm{H}]^{-}\right), 61\left(\mathrm{~m} / z 529.13367[\mathrm{M}-\mathrm{H}]^{-}\right)$ (Figure S15), $66\left(\mathrm{~m} / \mathrm{z} 543.15027[\mathrm{M}-\mathrm{H}]^{-}\right)$, and $74\left(\mathrm{~m} / \mathrm{z} 543.15080[\mathrm{M}-\mathrm{H}]^{-}\right)$(Figure S16) were identified as methyl 4,5-dicaffeoylquinate (4,5-diCQM), 3,5-diCQM, 3,4-diCQM, ethyl 4,5-dicaffeoylquinate (3,5-diCQE), and 3,4-diCQE, respectively, by comparing with reference standards isolated from $P$. indica. Their MS/MS fragment patterns were similar to those of CQMs mentioned above. In detail, in the MS/MS spectra of 4,5-diCQM (peak 51), 3,5-diCQM (peak 55), and 3,5-diCQE (peak 66), the base peak ion was $m / z 161.02306$ [529.13515 - $\left.\mathrm{C}_{9} \mathrm{H}_{6} \mathrm{O}_{3}-\mathrm{C}_{7} \mathrm{H}_{12} \mathrm{O}_{6}-\mathrm{CH}_{2}\right]^{-}, 161.02304$ [529.13515- $\mathrm{C}_{9} \mathrm{H}_{6} \mathrm{O}_{3}-$ $\left.\mathrm{C}_{7} \mathrm{H}_{12} \mathrm{O}_{6}-\mathrm{CH}_{2}\right]^{-}$, and 161.02316 [543.15080 $\left.-\mathrm{C}_{9} \mathrm{H}_{6} \mathrm{O}_{3}-\mathrm{C}_{7} \mathrm{H}_{12} \mathrm{O}_{6}-\mathrm{C}_{2} \mathrm{H}_{4}\right]^{-}$, respectively. What is more, and the abundance of $m / z 135.04356$ [529.13515- $\left.\mathrm{C}_{9} \mathrm{H}_{6} \mathrm{O}_{3}-\mathrm{C}_{7} \mathrm{H}_{10} \mathrm{O}_{5}-\mathrm{CH}_{2}-\mathrm{CO}_{2}\right]^{-}$and 133.02808 [543.15080 - $\mathrm{C}_{9} \mathrm{H}_{6} \mathrm{O}_{3}-\mathrm{C}_{7} \mathrm{H}_{12} \mathrm{O}_{6}-\mathrm{C}_{2} \mathrm{H}_{4}-\mathrm{CO}^{-}$was also strong in the MS/MS spectra of 55 and 66, respectively. While, $m / z 135.04364\left[\mathrm{M}-\mathrm{H}-\mathrm{C}_{9} \mathrm{H}_{6} \mathrm{O}_{3}-\mathrm{C}_{7} \mathrm{H}_{10} \mathrm{O}_{5}-\mathrm{CH}_{2}-\mathrm{CO}_{2}\right]^{-}$and $135.04370[\mathrm{M}-\mathrm{H}-$ $\left.\mathrm{C}_{9} \mathrm{H}_{6} \mathrm{O}_{3}-\mathrm{C}_{7} \mathrm{H}_{10} \mathrm{O}_{5}-\mathrm{C}_{2} \mathrm{H}_{4}-\mathrm{CO}_{2}\right]^{-}$was the base peak for the MS/MS spectra of 3,4-diCQM (peak 61) and 3,4-diCQE (peak 74), respectively. These indicated when 3- and/or 5-OH of CQMs/CQEs were substituted by caffeoyl; the base peak ion was at $m / z 135.04406$ or 161.02332 . On the other hand, their chromatographic elution order (4,5-diCQM (peak 51, $t_{\mathrm{R}} 37.80 \mathrm{~min}$ ) <3,5-diCQM (peak 55, $t_{\mathrm{R}} 38.39 \mathrm{~min}$ ) $<3,4$-diCQM (peak 61, $t_{\mathrm{R}} 39.49 \mathrm{~min}$ ); 3,5-diCQE (peak 66, $t_{\mathrm{R}} 40.16 \mathrm{~min}$ ) <3,4-diCQE (peak 74, $t_{\mathrm{R}}$ $41.61 \mathrm{~min})$ ) was consistent with that of di-CQAs. As a result, peak $50\left(\mathrm{~m} / z 529.13515[\mathrm{M}-\mathrm{H}]^{-}\right)$was tentatively identified as 1,4-diCQM according to the base peak ions $m / z 191.05522\left[\mathrm{M}-\mathrm{H}-2 \mathrm{C}_{9} \mathrm{H}_{6} \mathrm{O}_{3}-\right.$ $\left.\mathrm{CH}_{2}\right]^{-}$and its $t_{R}$ (peak 50, $37.55 \mathrm{~min}$ ). According to the base peak ions $m / z 161.02313\left[\mathrm{M}-\mathrm{H}-\mathrm{C}_{9} \mathrm{H}_{6} \mathrm{O}_{3}-\right.$ 
$\left.\mathrm{C}_{2} \mathrm{H}_{4}-\mathrm{C}_{7} \mathrm{H}_{12} \mathrm{O}_{6}\right]^{-}$and the $t_{R}$ (peak 62, $39.59 \mathrm{~min}$ ) (Figure S16), peak $62\left(\mathrm{~m} / z 543.15080[\mathrm{M}-\mathrm{H}]^{-}\right)$was tentatively identified as 1,5-diCQE or 4,5-diCQE.

It was visible from the above derivation processes that CQFAs were confusing with diCQMs as they possessed the same molecular. The key to distinguish them was the presence of characteristic fragment ions at $m / z 193.04954$ and 134.03623 for the feruloyl group, or not [23].

Peaks $47\left(\mathrm{~m} / z 677.15277[\mathrm{M}-\mathrm{H}]^{-}\right), 53\left(\mathrm{~m} / z 677.15070[\mathrm{M}-\mathrm{H}]^{-}\right)$, and $65\left(\mathrm{~m} / z 677.15270[\mathrm{M}-\mathrm{H}]^{-}\right)$ (Figure S17) were unambiguously identified as 1,3,5-tricaffeoyl quinic acid (1,3,5-triCQA), 1,3,4-triCQA, 3,4,5-triCQA, respectively, by comparing with reference standards obtained from $P$. indica. As we have mentioned above, the quinic acid aglycone could be substituted by multiple acyls at its 1-, 3-, 4-, and 5-hydroxyl, thus the possibilities of triCQAs included 1,3,5-triCQA, 1,3,4-triCQA, 1,4,5-triCQA, and 3,4,5-triCQA. Then, another triCQA (peak 63) should be deduced to be 1,4,5-triCQA.

Peak $76\left(\mathrm{~m} / \mathrm{z} 839.18289[\mathrm{M}-\mathrm{H}]^{-}\right.$) (Figure S18), was definitely confirmed to be 1,3,4,5-tetracaffeoyl quinic acid (1,3,4,5-tetraCQA) by comparing with reference standards. Peak $92\left(\mathrm{~m} / \mathrm{z} 867.21393[\mathrm{M}-\mathrm{H}]^{-}\right)$ (Figure S18) was tentatively identified as ethyl 1,3,4,5-tetracaffeoyl quinate (1,3,4,5-tetraCQE), because of the lack of feruloyl group characteristic fragment ions as well as the similarity of its MS/MS spectra with that of 1,3,4,5-tetraCQM (peak 76) (Figure S18). What is more, peak 92 was possible to be a new compound.

Peak $91\left(\mathrm{~m} / \mathrm{z} 691.16684[\mathrm{M}-\mathrm{H}]^{-}\right)$(Figure S19) was definitely identified as methyl 3,4,5-tricaffeoyl quinate (3,4,5-triCQM) by comparing with reference standards. In the MS/MS spectrum of peak 80 $\left(\mathrm{m} / \mathrm{z} 691.16754[\mathrm{M}-\mathrm{H}]^{-}\right)$(Figure S19), feruloyl group characteristic fragment ions $\mathrm{m} / \mathrm{z} 193.04954$ and 134.03623 were lacking, while $m / z 179.03\left[\mathrm{M}-\mathrm{H}-2 \mathrm{C}_{9} \mathrm{H}_{6} \mathrm{O}_{3}-\mathrm{C}_{7} \mathrm{H}_{10} \mathrm{O}_{5}-\mathrm{CH}_{2}\right]^{-}$for caffeoyl group was observed, thus it was speculated to be a triCQM. Because of the lack of samples for summary of MS fragment pathway and retention time rules, peak $\mathbf{8 0}$ was tentatively deduced to be 1,3,4-triCQM or 1,3,5-triCQM or 1,4,5-triCQM. In addition, owing to the lack of feruloyl group characteristic fragment ions, and its MS/MS spectrum was similar to that of 3,4,5-triCQM (peak 91), peak $98(\mathrm{~m} / \mathrm{z} 705.18036$ $[\mathrm{M}-\mathrm{H}]^{-}$) (Figure S19) was tentatively identified as ethyl 3,4,5-tricaffeoyl quinate (3,4,5-triCQE). Moreover, peak 98 is potentially novel.

Meanwhile using a similar manner mentioned above, the structure types of the remaining 13 acyl-substituted quinic acids and their derivatives were tentatively proposed (Table 1). 
Table 1. The qualitative analysis of compounds 1-114 by ESI-Q-Orbitrap mass spectrometry (MS).

\begin{tabular}{|c|c|c|c|c|c|c|c|c|}
\hline No. & $t_{\mathrm{R}}(\min )$ & Compound & Formula & Adduct Ions & Theoretic & Measure & Diff (ppm) & Identification Fragment Ions $(\mathrm{m} / \mathrm{z}$ ) (Intensity) \\
\hline 1 & 3.17 & 3,4-Dihydroxy benzoic acid * & $\mathrm{C}_{7} \mathrm{H}_{6} \mathrm{O}_{4}$ & {$[\mathrm{M}-\mathrm{H}]^{-}$} & 153.01933 & 153.01914 & -1.24 & $109.02793(100)$ \\
\hline 2 & 3.51 & Adenosine* & $\mathrm{C}_{10} \mathrm{H}_{13} \mathrm{~N}_{5} \mathrm{O}_{4}$ & {$[\mathrm{M}-\mathrm{H}]^{-}$} & 266.08948 & 266.08969 & 0.79 & $134.04578(100)$ \\
\hline 3 & 4.26 & 5-TQA & $\mathrm{C}_{16} \mathrm{H}_{18} \mathrm{O}_{10}$ & {$[\mathrm{M}-\mathrm{H}]^{-}$} & 369.08272 & 369.08298 & 0.70 & $195.02939(16), 191.05483(100), 133.02803(82)$ \\
\hline 4 & 4.97 & $5-\mathrm{CQA} *$ & $\mathrm{C}_{16} \mathrm{H}_{18} \mathrm{O}_{9}$ & {$[\mathrm{M}-\mathrm{H}]^{-}$} & 353.08781 & 353.08826 & 1.27 & $191.05497(100), 179.03378(54), 135.04367$ (62) \\
\hline 5 & 5.27 & $\begin{array}{l}\text { 2,3-Dihydroxy-1-(4-hydroxy-3- } \\
\text { methoxyphenyl)-propan-1-one* }\end{array}$ & $\mathrm{C}_{10} \mathrm{H}_{12} \mathrm{O}_{5}$ & {$[\mathrm{M}-\mathrm{H}]^{-}$} & 211.06120 & 211.06069 & -2.41 & $181.04950(100), 163.03879(88)$ \\
\hline 6 & 5.28 & $p$-Hydroxybenzoic acid * & $\mathrm{C}_{7} \mathrm{H}_{6} \mathrm{O}_{3}$ & {$[\mathrm{M}-\mathrm{H}]^{-}$} & 137.02442 & 137.02309 & -0.23 & $93.03307(100)$ \\
\hline 7 & 5.54 & 3,4-Dihydroxybenzaldehyde * & $\mathrm{C}_{7} \mathrm{H}_{6} \mathrm{O}_{3}$ & {$[\mathrm{M}-\mathrm{H}]^{-}$} & 137.02442 & 137.02413 & -2.12 & $109.02798(14)$ \\
\hline 8 & 6.69 & Methyl 3,4-dihydroxybenzoate & $\mathrm{C}_{8} \mathrm{H}_{8} \mathrm{O}_{4}$ & {$[\mathrm{M}-\mathrm{H}]^{-}$} & 167.03498 & 167.03418 & -4.79 & $152.01022(100), 108.02016(2)$ \\
\hline 9 & 7.39 & 3-TQA & $\mathrm{C}_{16} \mathrm{H}_{18} \mathrm{O}_{10}$ & {$[\mathrm{M}-\mathrm{H}]^{-}$} & 369.08272 & 369.08316 & -1.19 & $195.02869(60), 133.02803(100)$ \\
\hline 10 & 8.13 & 3,4-Dihydroxy-5-methoxybenzaldehyde * & $\mathrm{C}_{8} \mathrm{H}_{8} \mathrm{O}_{4}$ & {$[\mathrm{M}-\mathrm{H}]^{-}$} & 167.03498 & 167.03424 & -4.43 & $152.01013(100), 124.01488(3)$ \\
\hline 11 & 8.20 & $3-\mathrm{CQA}$ * & $\mathrm{C}_{16} \mathrm{H}_{18} \mathrm{O}_{9}$ & {$[\mathrm{M}-\mathrm{H}]^{-}$} & 353.08781 & 353.08820 & 1.10 & $191.05495(100), 179.03383(1), 135.04362(1)$ \\
\hline 12 & 8.41 & 3-Methoxy-4-hydroxybenzoic acid * & $\mathrm{C}_{8} \mathrm{H}_{8} \mathrm{O}_{4}$ & {$[\mathrm{M}-\mathrm{H}]^{-}$} & 167.03498 & 167.03430 & -4.07 & $152.01022(100), 123.04363(8), 108.02016(21)$ \\
\hline 13 & 9.30 & Esculetin * & $\mathrm{C}_{9} \mathrm{H}_{6} \mathrm{O}_{4}$ & {$[\mathrm{M}-\mathrm{H}]^{-}$} & 177.01933 & 177.01863 & -3.95 & $141.8685(72), 133.02802(100)$ \\
\hline 14 & 9.41 & Caffiec acid * & $\mathrm{C}_{9} \mathrm{H}_{8} \mathrm{O}_{4}$ & {$[\mathrm{M}-\mathrm{H}]^{-}$} & 179.03498 & 179.03427 & -3.97 & $135.04359(100)$ \\
\hline 15 & 10.26 & 4-TQA & $\mathrm{C}_{16} \mathrm{H}_{18} \mathrm{O}_{10}$ & {$[\mathrm{M}-\mathrm{H}]^{-}$} & 369.08272 & 369.08322 & 1.35 & $195.02857(11), 173.04421(100)$ \\
\hline 16 & 10.69 & 4-CQA * & $\mathrm{C}_{16} \mathrm{H}_{18} \mathrm{O}_{9}$ & {$[\mathrm{M}-\mathrm{H}]^{-}$} & 353.08781 & 353.08762 & -0.54 & $\begin{array}{c}191.05493(49), \\
179.03373(66), 173.04429(100), \\
135.04366(72)\end{array}$ \\
\hline 17 & 12.03 & 2-Hydroxybenzoic acid or 3-Hydroxybenzoic acid & $\mathrm{C}_{7} \mathrm{H}_{6} \mathrm{O}_{3}$ & {$[\mathrm{M}-\mathrm{H}]^{-}$} & 137.02442 & 137.02413 & -2.12 & $93.03311(100)$ \\
\hline 18 & 14.27 & $3-C o Q A$ & $\mathrm{C}_{16} \mathrm{H}_{18} \mathrm{O}_{8}$ & {$[\mathrm{M}-\mathrm{H}]^{-}$} & 337.09289 & 337.09384 & 2.82 & $191.05482(100), 163.03868(9)$ \\
\hline 19 & 17.63 & Vanillin * & $\mathrm{C}_{8} \mathrm{H}_{8} \mathrm{O}_{3}$ & {$[\mathrm{M}-\mathrm{H}]^{-}$} & 151.04007 & 151.03996 & -0.73 & $136.01509(100), 109.02799(7)$ \\
\hline 20 & 18.44 & 4-CoQA & $\mathrm{C}_{16} \mathrm{H}_{18} \mathrm{O}_{8}$ & {$[\mathrm{M}-\mathrm{H}]^{-}$} & 337.09289 & 337.09351 & 1.84 & $173.04419(100), 163.03868$ (19) \\
\hline 21 & 19.61 & 5-FQA & $\mathrm{C}_{17} \mathrm{H}_{20} \mathrm{O}_{9}$ & {$[\mathrm{M}-\mathrm{H}]^{-}$} & 367.10346 & 367.10382 & 0.98 & $193.04926(1), 161.02310(100)$ \\
\hline 22 & 19.94 & 3-FQA & $\mathrm{C}_{17} \mathrm{H}_{20} \mathrm{O}_{9}$ & {$[\mathrm{M}-\mathrm{H}]^{-}$} & 367.10346 & 367.10373 & 0.74 & $193.04933(7), 191.05495$ (100) \\
\hline 23 & 20.82 & Syringicaldehyde * & $\mathrm{C}_{9} \mathrm{H}_{10} \mathrm{O}_{4}$ & {$[\mathrm{M}-\mathrm{H}]^{-}$} & 181.05063 & 181.05087 & 1.59 & $166.02563(100), 151.00235(86)$ \\
\hline 24 & 21.24 & 4-FQA & $\mathrm{C}_{17} \mathrm{H}_{20} \mathrm{O}_{9}$ & {$[\mathrm{M}-\mathrm{H}]^{-}$} & 367.10346 & 367.10376 & 0.82 & $193.04939(17), 173.04428(100)$ \\
\hline 25 & 21.28 & Monosulfonyl substituted flavone & $\mathrm{C}_{15} \mathrm{H}_{10} \mathrm{O}_{10} \mathrm{~S}$ & {$[\mathrm{M}-\mathrm{H}]^{-}$} & 380.99219 & 380.99155 & 1.68 & $301.03424(100), 178.99715(2), 151.00209(10)$ \\
\hline 26 & 21.73 & Monosulfonyl substituted flavone & $\mathrm{C}_{15} \mathrm{H}_{10} \mathrm{O}_{10} \mathrm{~S}$ & {$[\mathrm{M}-\mathrm{H}]^{-}$} & 380.99219 & 380.99167 & -1.36 & $301.03586(100), 178.99789(25), 151.00278$ (65) \\
\hline 27 & 21.80 & Disulfonyl substituted flavone & $\mathrm{C}_{15} \mathrm{H}_{10} \mathrm{O}_{13} \mathrm{~S}_{2}$ & {$[\mathrm{M}-\mathrm{H}]^{-}$} & 460.94900 & 460.94988 & 1.91 & $\begin{array}{c}380.99248(75), 301.03577(100), 178.99805(19), \\
151.00278(40), 96.95886(18)\end{array}$ \\
\hline 28 & 22.29 & $5-\mathrm{CQM}$ & $\mathrm{C}_{17} \mathrm{H}_{20} \mathrm{O}_{9}$ & {$[\mathrm{M}-\mathrm{H}]^{-}$} & 367.10346 & 367.10373 & 0.74 & $\begin{array}{c}179.03380(7), 173.04451(1), 161.02313(100) \\
133.02809(28)\end{array}$ \\
\hline 29 & 23.12 & $3-\mathrm{CQM} *$ & $\mathrm{C}_{17} \mathrm{H}_{20} \mathrm{O}_{9}$ & {$[\mathrm{M}-\mathrm{H}]^{-}$} & 367.10346 & 367.10379 & 0.90 & $179.03371(55), 161.02318(26), 135.04358(100)$ \\
\hline 30 & 23.73 & Monosulfonyl substituted flavone & $\mathrm{C}_{15} \mathrm{H}_{10} \mathrm{O}_{10} \mathrm{~S}$ & {$[\mathrm{M}-\mathrm{H}]^{-}$} & 380.99219 & 380.99255 & 0.94 & $301.03479(100), 178.99739(21), 151.00240(53)$ \\
\hline 31 & 24.73 & Quercetin-3-O- $\beta$-D-galactopyranoside * & $\mathrm{C}_{21} \mathrm{H}_{20} \mathrm{O}_{12}$ & {$[\mathrm{M}+\mathrm{H}]^{+}$} & 463.08820 & 463.08654 & -3.58 & $\begin{array}{c}300.02689(100), 271.02435(51), 255.02951(23), \\
243.02861(10)\end{array}$ \\
\hline 32 & 25.48 & Quercetin-3-O- $\beta$-D-glucopyranoside * & $\mathrm{C}_{21} \mathrm{H}_{20} \mathrm{O}_{12}$ & {$[\mathrm{M}+\mathrm{H}]^{+}$} & 463.08820 & 463.08749 & -1.53 & $\begin{array}{c}300.03(100), 271.02424(71), 255.02955(31) \\
243.02860(13)\end{array}$ \\
\hline 33 & 26.49 & $(+)$-Isolariciresinol * & $\mathrm{C}_{20} \mathrm{H}_{24} \mathrm{O}_{6}$ & {$[\mathrm{M}-\mathrm{H}]^{-}$} & 359.15001 & 359.14966 & -0.97 & ND \\
\hline 34 & 26.87 & trans-Ferulic acid * & $\mathrm{C}_{10} \mathrm{H}_{10} \mathrm{O}_{4}$ & {$[\mathrm{M}-\mathrm{H}]^{-}$} & 193.05063 & 193.05017 & -2.38 & $161.02310(28), 133.02797(19)$ \\
\hline
\end{tabular}


Table 1. Cont.

\begin{tabular}{|c|c|c|c|c|c|c|c|c|}
\hline 35 & 27.11 & 1,4-DiCQA * & $\mathrm{C}_{25} \mathrm{H}_{24} \mathrm{O}_{12}$ & {$[\mathrm{M}-\mathrm{H}]^{-}$} & 515.11950 & 515.11865 & -1.65 & $\begin{array}{c}353.08719(60), 191.05486(46), 179.03369(69), \\
173.04434(100), 135.04370(77)\end{array}$ \\
\hline 36 & 27.63 & Kaempferol-O-galactopyranoside & $\mathrm{C}_{21} \mathrm{H}_{20} \mathrm{O}_{11}$ & {$[\mathrm{M}-\mathrm{H}]^{-}$} & 447.09328 & 447.09430 & 2.28 & $284.03174(84), 255.02882(100), 227.03365$ (82) \\
\hline 37 & 27.99 & 1,5-DiCQA * & $\mathrm{C}_{25} \mathrm{H}_{24} \mathrm{O}_{12}$ & {$[\mathrm{M}-\mathrm{H}]^{-}$} & 515.11950 & 515.12067 & 2.27 & $\begin{array}{c}353.08688(17), 191.05472(100), 179.03371(5), \\
161.02297(5), 135.04356(6)\end{array}$ \\
\hline 38 & 28.22 & 1,3-DiCQA * & $\mathrm{C}_{25} \mathrm{H}_{24} \mathrm{O}_{12}$ & {$[\mathrm{M}-\mathrm{H}]^{-}$} & 515.11950 & 515.11871 & -1.53 & $\begin{array}{c}353.08694(12), 191.05495(100), 179.03365(4), \\
161.02303(5), 135.04370(6)\end{array}$ \\
\hline 39 & 28.68 & 4,5-DiCQA * & $\mathrm{C}_{25} \mathrm{H}_{24} \mathrm{O}_{12}$ & {$[\mathrm{M}-\mathrm{H}]^{-}$} & 515.11950 & 515.12006 & 1.09 & $\begin{array}{c}353.08713(59), 191.05493(53), 179.03375(84), \\
173.04420(100), 161.02312(37), 155.03355(14) \\
135.04362(85)\end{array}$ \\
\hline 40 & 28.89 & 3,5-DiCQA * & $\mathrm{C}_{25} \mathrm{H}_{24} \mathrm{O}_{12}$ & {$[\mathrm{M}-\mathrm{H}]^{-}$} & 515.11950 & 515.11888 & -1.20 & $\begin{array}{c}353.08697(57), 191.05480(100), 179.03369(51) \\
173.04446(5), 135.04363(54)\end{array}$ \\
\hline 41 & 29.23 & Monosulfonyl substituted methoxyflavone & $\mathrm{C}_{16} \mathrm{H}_{12} \mathrm{O}_{10} \mathrm{~S}$ & {$[\mathrm{M}-\mathrm{H}]^{-}$} & 395.00784 & 395.00778 & -0.15 & $\begin{array}{c}315.05048(100), 300.02689(41), 271.02438(26) \\
255.02913(13), 243.02908(6)\end{array}$ \\
\hline 42 & 29.63 & Kaempferol 3-O- $\beta$-D-glucopyranoside * & $\mathrm{C}_{21} \mathrm{H}_{20} \mathrm{O}_{11}$ & {$[\mathrm{M}-\mathrm{H}]^{-}$} & 447.09328 & 447.09423 & 2.12 & 284.03159 (79), $255.02875(100), 227.03368$ (87) \\
\hline 43 & 30.39 & Cynaroside * & $\mathrm{C}_{21} \mathrm{H}_{20} \mathrm{O}_{11}$ & {$[\mathrm{M}-\mathrm{H}]^{-}$} & 447.09328 & 447.09406 & 1.74 & ND \\
\hline 44 & 31.20 & $\begin{array}{l}\text { 5,7,3',4'-Tetrahydroxy-3-methoxy } \\
\text { flavonol-3'-O- } \beta \text {-D-glucopyranoside * }\end{array}$ & $\mathrm{C}_{22} \mathrm{H}_{22} \mathrm{O}_{12}$ & {$[\mathrm{M}-\mathrm{H}]^{-}$} & 477.10385 & 477.10520 & 2.83 & 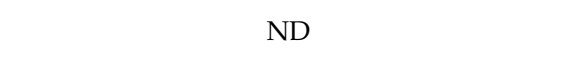 \\
\hline 45 & 33.94 & 3,4-DiCQA * & $\mathrm{C}_{25} \mathrm{H}_{24} \mathrm{O}_{12}$ & {$[\mathrm{M}-\mathrm{H}]^{-}$} & 515.11950 & 515.12002 & 1.01 & $\begin{array}{c}353.08701 \text { (71), } 191.05498(37), 179.03368(64), \\
173.04430(100), 135.04367 \text { (62) }\end{array}$ \\
\hline 46 & 36.21 & 1-C-5-F-QA or 1-F-5-C-QA & $\mathrm{C}_{26} \mathrm{H}_{26} \mathrm{O}_{12}$ & {$[\mathrm{M}-\mathrm{H}]^{-}$} & 529.13515 & 529.13550 & 0.66 & $\begin{array}{c}367.10258(21), 353.08741(22), 349.09223(20), \\
335.07694(25), 193.04936(93), 179.03373(66), \\
173.04420(83), 161.02299(42), 155.03351(39), \\
135.04369(68), 134.03582(100)\end{array}$ \\
\hline 47 & 36.63 & 1,3,5-TriCQA * & $\mathrm{C}_{34} \mathrm{H}_{30} \mathrm{O}_{15}$ & {$[\mathrm{M}-\mathrm{H}]^{-}$} & 677.15119 & 677.15155 & 0.53 & $\begin{array}{c}515.11898(5), 497.10879(10), 353.08703(50), \\
335.07655(13), 191.05478(100), 179.03362(70) \\
173.04419(11), 161.02305(23), 135.04358(64)\end{array}$ \\
\hline 48 & 37.15 & 1-C-3-FQA & $\mathrm{C}_{26} \mathrm{H}_{26} \mathrm{O}_{12}$ & {$[\mathrm{M}-\mathrm{H}]^{-}$} & 529.13515 & 529.13581 & 1.25 & $\begin{array}{c}367.10327(43), 191.05527(100), 173.04451(54) \\
161.02300(12), 134.03579(18)\end{array}$ \\
\hline 49 & 37.30 & 3-F-5-CQA & $\mathrm{C}_{26} \mathrm{H}_{26} \mathrm{O}_{12}$ & {$[\mathrm{M}-\mathrm{H}]^{-}$} & 529.13515 & 529.13574 & 1.12 & $\begin{array}{c}367.10309 \text { (42), } 193.04980(100), 173.04443(21) \\
134.03607(81)\end{array}$ \\
\hline 50 & 37.49 & 1,4-DiCQM & $\mathrm{C}_{26} \mathrm{H}_{26} \mathrm{O}_{12}$ & {$[\mathrm{M}-\mathrm{H}]^{-}$} & 529.13515 & 529.13416 & -1.87 & $\begin{array}{c}367.10264(24), 353.08711(29), 191.05522(100) \\
179.03364(38), 161.02306(40), 135.04353(50)\end{array}$ \\
\hline 51 & 37.77 & 4,5-DiCQM * & $\mathrm{C}_{26} \mathrm{H}_{26} \mathrm{O}_{12}$ & {$[\mathrm{M}-\mathrm{H}]^{-}$} & 529.13515 & 529.13501 & -0.26 & $\begin{array}{c}367.10242(15), 179.03372(4), 161.02308(100) \\
133.02805(28)\end{array}$ \\
\hline 52 & 37.91 & Ethyl caffeate * & $\mathrm{C}_{11} \mathrm{H}_{12} \mathrm{O}_{4}$ & {$[\mathrm{M}-\mathrm{H}]^{-}$} & 207.06628 & 207.06556 & -3.48 & $\begin{array}{c}179.03377(27), 159.85886(41), 135.04372(44), \\
127.86897(35), 103.91862(14)\end{array}$ \\
\hline 53 & 38.22 & 1,3,4-TriCQA * & $\mathrm{C}_{34} \mathrm{H}_{30} \mathrm{O}_{15}$ & {$[\mathrm{M}-\mathrm{H}]^{-}$} & 677.15119 & 677.15070 & -0.72 & $\begin{array}{c}515.11847(34), 497.10794(18), 353.08694(19), \\
335.07701(10), 191.05501(46), 179.03377(100) \\
173.04422(83), 161.02305(78), 135.04367(83)\end{array}$ \\
\hline 54 & 38.32 & Quercetin* & $\mathrm{C}_{15} \mathrm{H}_{10} \mathrm{O}_{7}$ & {$[\mathrm{M}-\mathrm{H}]^{-}$} & 301.03538 & 301.03571 & 1.10 & $\begin{array}{c}272.02643(6), 178.99734(24), 151.00224(70) \\
121.02786(19), 107.01236(19)\end{array}$ \\
\hline
\end{tabular}


Table 1. Cont.

\begin{tabular}{|c|c|c|c|c|c|c|c|c|}
\hline 55 & 38.39 & 3,5-DiCQM * & $\mathrm{C}_{26} \mathrm{H}_{26} \mathrm{O}_{12}$ & {$[\mathrm{M}-\mathrm{H}]^{-}$} & 529.13515 & 529.13519 & 0.08 & $\begin{array}{c}367.10275(22), 179.03320(31), 161.02304(100), \\
135.04358(45)\end{array}$ \\
\hline 56 & 38.45 & Triethyl citrate * & $\mathrm{C}_{12} \mathrm{H}_{20} \mathrm{O}_{7}$ & {$[\mathrm{M}-\mathrm{H}]^{-}$} & 275.11362 & 275.11278 & -3.05 & ND \\
\hline 57 & 38.49 & Luteolin * & $\mathrm{C}_{15} \mathrm{H}_{10} \mathrm{O}_{6}$ & {$[\mathrm{M}-\mathrm{H}]^{-}$} & 285.04046 & 285.04114 & 2.39 & $151.00223(10), 133.02827(32)$ \\
\hline 58 & 38.79 & CFQM-1 & $\mathrm{C}_{27} \mathrm{H}_{28} \mathrm{O}_{12}$ & {$[\mathrm{M}-\mathrm{H}]^{-}$} & 543.15080 & 543.14954 & -2.32 & $\begin{array}{c}367.10281(13), 349.09195(75), 193.04941(75), \\
173.04420(95), 161.02319(9), 155.03357(42) \\
134.03580(100)\end{array}$ \\
\hline 59 & 39.04 & $\begin{array}{c}(-)-\left(7 S, 7^{\prime} S, 8 R, 8^{\prime} R\right)-4,4^{\prime}-\text {-Dihydroxy- } \\
3,3^{\prime}, 5,5^{\prime} \text {-pentamethoxy-7,9': } 7^{\prime}, 9-\text { diepoxylignane * }\end{array}$ & $\mathrm{C}_{22} \mathrm{H}_{26} \mathrm{O}_{8}$ & {$[\mathrm{M}-\mathrm{H}]^{-}$} & 415.15748 & 415.15757 & 0.22 & ND \\
\hline 60 & 39.39 & 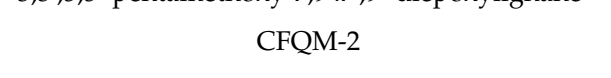 & $\mathrm{C}_{27} \mathrm{H}_{28} \mathrm{O}_{12}$ & {$[\mathrm{M}-\mathrm{H}]^{-}$} & 543.15080 & 543.15009 & -1.31 & $\begin{array}{c}367.10251(25), 349.09210(18), 193.04941 \text { (100), } \\
161.02301(49), 134.03583(18)\end{array}$ \\
\hline 61 & 39.49 & 3,4-DiCQM * & $\mathrm{C}_{26} \mathrm{H}_{26} \mathrm{O}_{12}$ & {$[\mathrm{M}-\mathrm{H}]^{-}$} & 529.13515 & 529.13562 & 0.89 & $\begin{array}{c}367.10202(17), 179.03372(69), 161.02311(63) \\
135.04359(100)\end{array}$ \\
\hline 62 & 39.59 & 1,5-DiCQE/4,5-DiCQE & $\mathrm{C}_{27} \mathrm{H}_{28} \mathrm{O}_{12}$ & {$[\mathrm{M}-\mathrm{H}]^{-}$} & 543.15080 & 543.15125 & 0.83 & $\begin{array}{l}381.11993(12), 161.02313(100), 133.02809(28) \\
515.11743(15), 353.08701(55), 191.05486(43),\end{array}$ \\
\hline 63 & 39.85 & 1,4,5-TriCQA & $\mathrm{C}_{34} \mathrm{H}_{30} \mathrm{O}_{15}$ & {$[\mathrm{M}-\mathrm{H}]^{-}$} & 677.15119 & 677.15173 & 0.80 & $\begin{array}{c}179.03371(89), \\
173.04424(100), 161.02301(33), \\
135.04364(80)\end{array}$ \\
\hline 64 & 39.89 & Methyl 9-hydroxynonanoate * & $\mathrm{C}_{10} \mathrm{H}_{20} \mathrm{O}_{3}$ & {$[\mathrm{M}-\mathrm{H}]^{-}$} & 187.13397 & 187.13403 & 0.32 & $\begin{array}{c}141.12700(100) \\
51511885(20)\end{array}$ \\
\hline 65 & 40.13 & 3,4,5-TriCQA * & $\mathrm{C}_{34} \mathrm{H}_{30} \mathrm{O}_{15}$ & {$[\mathrm{M}-\mathrm{H}]^{-}$} & 677.15119 & 677.15179 & 0.89 & $\begin{array}{c}515.11885(22), 353.08701(33), 191.05479(61), \\
179.03371(96), \\
173.04419(100), 161.02303(43), \\
135.04364(84)\end{array}$ \\
\hline 66 & 40.13 & 3,5-DiCQE * & $\mathrm{C}_{27} \mathrm{H}_{28} \mathrm{O}_{12}$ & {$[\mathrm{M}-\mathrm{H}]^{-}$} & 543.15080 & 543.15094 & 0.26 & $\begin{array}{c}381.11856(20), 179.03387(33), 161.02316(100), \\
133.02808(32)\end{array}$ \\
\hline 67 & 40.33 & CFQM-3 & $\mathrm{C}_{27} \mathrm{H}_{28} \mathrm{O}_{12}$ & {$[\mathrm{M}-\mathrm{H}]^{-}$} & 543.15080 & 543.15118 & 0.70 & $\begin{array}{l}367.10272(23), 349.09177(33), 193.04958(34), \\
179.03358(60), 173.04431(17), 161.02312(80), \\
135.04375(100), 134.03601(39), 133.02805(26)\end{array}$ \\
\hline 68 & 40.34 & 5,6,4'-Trihydroxy-3,7-dimethoxyflavone * & $\mathrm{C}_{17} \mathrm{H}_{14} \mathrm{O}_{7}$ & {$[\mathrm{M}-\mathrm{H}]^{-}$} & 329.06667 & 329.06669 & 0.06 & $\begin{array}{c}314.04276(100), 299.01917(94), 271.02429(33), \\
243.02908(13)\end{array}$ \\
\hline 69 & 40.84 & CFQM-4 & $\mathrm{C}_{27} \mathrm{H}_{28} \mathrm{O}_{12}$ & {$[\mathrm{M}-\mathrm{H}]^{-}$} & 543.15080 & 543.15088 & 0.15 & $\begin{array}{c}193.04944(13), 161.02306(100), 134.03596(20), \\
133.02803(34)\end{array}$ \\
\hline 70 & 41.10 & TriMethoxyflavone & $\mathrm{C}_{18} \mathrm{H}_{16} \mathrm{O}_{8}$ & {$[\mathrm{M}-\mathrm{H}]^{-}$} & 359.07724 & 359.07785 & 1.70 & $\begin{array}{l}344.05280(97), 329.02954(100), 314.00613(7) \\
301.03461(12), 286.01123(27), 258.01624(16)\end{array}$ \\
\hline 71 & 41.24 & Kaempferol * & $\mathrm{C}_{15} \mathrm{H}_{10} \mathrm{O}_{6}$ & {$[\mathrm{M}-\mathrm{H}]^{-}$} & 285.04046 & 285.03998 & -1.68 & $151.00218(2)$ \\
\hline 72 & 41.39 & CFQM-5 & $\mathrm{C}_{27} \mathrm{H}_{28} \mathrm{O}_{12}$ & {$[\mathrm{M}-\mathrm{H}]^{-}$} & 543.15080 & 543.15106 & 0.48 & $\begin{array}{c}349.09198(52), 193.04942(70), 179.03371(23), \\
161.02310(100), 135.04375(40), 134.03590(91), \\
133.02800(26)\end{array}$ \\
\hline 73 & 41.61 & 3,4-DiCQE * & $\mathrm{C}_{27} \mathrm{H}_{28} \mathrm{O}_{12}$ & {$[\mathrm{M}-\mathrm{H}]^{-}$} & 543.15080 & 543.15094 & 0.26 & $\begin{array}{c}381.11804(16), 161.02304(75), 179.03371(68) \\
135.04361(100)\end{array}$ \\
\hline 74 & 41.68 & $\begin{array}{l}\text { threo-2,3-Bis(4-hydroxy-3- } \\
\text { methoxyphenyl)-3-ethoxypropan-1-ol * }\end{array}$ & $\mathrm{C}_{19} \mathrm{H}_{24} \mathrm{O}_{6}$ & {$[\mathrm{M}-\mathrm{H}]^{-}$} & 347.15001 & 347.14891 & -3.17 & $161.02312(9), 135.04370(16)$ \\
\hline
\end{tabular}


Table 1. Cont.

\begin{tabular}{|c|c|c|c|c|c|c|c|c|}
\hline 75 & 41.91 & $\begin{array}{l}\text { 9,12,13-Trihydroxyoctadeca-10(E),15(Z)- } \\
\text { dienoic acid * }\end{array}$ & $\mathrm{C}_{18} \mathrm{H}_{32} \mathrm{O}_{5}$ & {$[\mathrm{M}-\mathrm{H}]^{-}$} & 327.21770 & 327.21742 & -0.86 & $229.14348(16), 211.13269(27), 171.10144(23)$ \\
\hline 76 & 41.98 & 1,3,4,5-TetraCQA * & $\mathrm{C}_{43} \mathrm{H}_{36} \mathrm{O}_{18}$ & {$[\mathrm{M}-\mathrm{H}]^{-}$} & 839.18289 & 839.18365 & 0.91 & $\begin{array}{l}659.13635(6), 515.11799(20), 353.08657(10), \\
335.07645(8), 191.05495(41), 179.03377(100), \\
173.04430(73), 161.02301(61), 135.04375(91)\end{array}$ \\
\hline 77 & 42.08 & Isorhamnetin * & $\mathrm{C}_{16} \mathrm{H}_{12} \mathrm{O}_{7}$ & {$[\mathrm{M}-\mathrm{H}]^{-}$} & 315.05103 & 315.05127 & 0.76 & $\begin{array}{c}300.02676(88), 271.02344(6), 164.01016(7) \\
151.00218(22)\end{array}$ \\
\hline 78 & 42.10 & CFQM-6 & $\mathrm{C}_{27} \mathrm{H}_{28} \mathrm{O}_{12}$ & {$[\mathrm{M}-\mathrm{H}]^{-}$} & 543.15080 & 543.15131 & 0.94 & $\begin{array}{c}349.09146(16), 193.04938(50), 161.02304(100), \\
135.04370(20), 134.03587(77), 133.02797(34)\end{array}$ \\
\hline 79 & 42.10 & 1,3,4-CCFQA & $\mathrm{C}_{35} \mathrm{H}_{32} \mathrm{O}_{15}$ & {$[\mathrm{M}-\mathrm{H}]^{-}$} & 691.16684 & 691.16785 & 1.46 & $\begin{array}{c}529.13403(10), 367.10284(20), 349.09241(9), \\
193.04938(100), 179.03378(73), 161.02312(58), \\
135.04370(44), 133.02805(84)\end{array}$ \\
\hline 80 & 42.32 & 1,3,4-TriCQM & $\mathrm{C}_{35} \mathrm{H}_{32} \mathrm{O}_{15}$ & {$[\mathrm{M}-\mathrm{H}]^{-}$} & 691.16684 & 691.16760 & 1.10 & $\begin{array}{c}529.1361(17), 515.11920(22), 353.08786(42), \\
367.10275(10), 335.07806(8), 191.05534(77), \\
179.03372(89), 173.04465(100), 161.02309(47), \\
155.03362(17), 135.04393(85)\end{array}$ \\
\hline 81 & 42.55 & $\begin{array}{l}\text { erythro-2,3-Bis(4-hydroxy-3- } \\
\text { methoxyphenyl)-3-ethoxypropan-1-ol * }\end{array}$ & $\mathrm{C}_{19} \mathrm{H}_{24} \mathrm{O}_{6}$ & {$[\mathrm{M}-\mathrm{H}]^{-}$} & 347.15001 & 347.14891 & -3.17 & $179.03271(81), 135.04364(100)$ \\
\hline 82 & 42.61 & $1,4,5-\mathrm{CCFQA}$ & $\mathrm{C}_{35} \mathrm{H}_{32} \mathrm{O}_{15}$ & {$[\mathrm{M}-\mathrm{H}]^{-}$} & 691.16684 & 691.16772 & 1.27 & $\begin{array}{c}529.13336(25), 367.10263(25), 335.07651(5), \\
193.04953(16), 179.03380(20), 173.04433(100), \\
161.02312(22), 155.03381(11), 135.04378(21), \\
133.02805(15)\end{array}$ \\
\hline 83 & 43.13 & Pinellic acid * & $\mathrm{C}_{18} \mathrm{H}_{34} \mathrm{O}_{5}$ & {$[\mathrm{M}-\mathrm{H}]^{-}$} & 329.23335 & 329.23300 & -1.06 & $229.14352(8), 211.13301(17), 171.10135$ (32) \\
\hline 84 & 43.58 & Trihydroxy-dimethoxyflavone & $\mathrm{C}_{17} \mathrm{H}_{14} \mathrm{O}_{7}$ & {$[\mathrm{M}-\mathrm{H}]^{-}$} & 329.06667 & 329.06705 & 1.15 & ND \\
\hline 85 & 43.87 & Caryolane-1,9ß-diol * & $\mathrm{C}_{15} \mathrm{H}_{26} \mathrm{O}_{2}$ & $\underset{H-\mathrm{H}_{2}^{+}}{\left[\mathrm{M}-\mathrm{H}^{+} \mathrm{O}\right.}$ & 221.18999 & 221.18954 & -2.03 & ND \\
\hline 86 & 44.19 & Chrysosplenol C* & $\mathrm{C}_{18} \mathrm{H}_{16} \mathrm{O}_{8}$ & {$[\mathrm{M}-\mathrm{H}]^{-}$} & 359.07724 & 359.07773 & 1.36 & $\begin{array}{c}344.05292(94), 329.02963(100), 286.01129(71) \\
344.05289(89), 329.02954(89), 344.05289(89),\end{array}$ \\
\hline 87 & 44.30 & Centaureidin * & $\mathrm{C}_{18} \mathrm{H}_{16} \mathrm{O}_{8}$ & {$[\mathrm{M}-\mathrm{H}]^{-}$} & 359.07724 & 359.07791 & 1.87 & $\begin{array}{c}329.02954(89), 314.00644(40), 301.03482(17), \\
286.01126(97)\end{array}$ \\
\hline 88 & 44.40 & CCCFQA-1 & $\mathrm{C}_{44} \mathrm{H}_{38} \mathrm{O}_{18}$ & {$[\mathrm{M}-\mathrm{H}]^{-}$} & 853.19854 & 853.19971 & 1.37 & $\begin{array}{l}645.15802(10), 529.13397(78), 335.07648(15), \\
193.04938(94), 179.03372(86), 173.04422(75), \\
161.02307(100), 155.03362(34), 135.04372(94)\end{array}$ \\
\hline 89 & 44.46 & CCFFQA-1 & $\mathrm{C}_{45} \mathrm{H}_{40} \mathrm{O}_{18}$ & {$[\mathrm{M}-\mathrm{H}]^{-}$} & 867.21419 & 867.21277 & -1.64 & $\begin{array}{c}193.04977 \text { (5), } 161.02315(100), 135.04369(11), \\
133.02803(47)\end{array}$ \\
\hline 90 & 44.77 & CCCFQA-2 & $\mathrm{C}_{44} \mathrm{H}_{38} \mathrm{O}_{18}$ & {$[\mathrm{M}-\mathrm{H}]^{-}$} & 853.19854 & 853.19946 & 1.08 & $\begin{array}{c}645.16498(3), 529.13361(29), 367.10287(9), \\
193.04933(20), 179.03880(21), 173.04419(100), \\
161.02298(27), 135.04361(26)\end{array}$ \\
\hline 91 & 44.93 & 3,4,5-TriCQM * & $\mathrm{C}_{35} \mathrm{H}_{32} \mathrm{O}_{15}$ & {$[\mathrm{M}-\mathrm{H}]^{-}$} & 691.16684 & 691.16754 & 1.01 & $\begin{array}{c}179.03409 \text { (29), } 161.02346(100), 135.04391(45), \\
133.02799(31)\end{array}$ \\
\hline 92 & 45.68 & 1,3,4,5-TetraCQE & $\mathrm{C}_{45} \mathrm{H}_{40} \mathrm{O}_{18}$ & {$[\mathrm{M}-\mathrm{H}]^{-}$} & 867.21419 & 867.21356 & -0.73 & $\begin{array}{c}355.08116(26), 179.03372(23), 161.02294(100), \\
135.04371(47), 133.02806(43)\end{array}$ \\
\hline
\end{tabular}


Table 1. Cont.

\begin{tabular}{|c|c|c|c|c|c|c|c|c|}
\hline 93 & 45.88 & Fraxinellone * & $\mathrm{C}_{14} \mathrm{H}_{16} \mathrm{O}_{3}$ & {$[\mathrm{M}+\mathrm{H}]^{+}$} & 233.11722 & 233.11784 & 2.66 & $215.10712(100), 187.11209(92)$ \\
\hline 94 & 46.07 & valenc-1(10)-ene-8,11-diol * & $\mathrm{C}_{15} \mathrm{H}_{26} \mathrm{O}_{2}$ & $\begin{array}{c}{\left[\mathrm{M}-\mathrm{H}_{2} \mathrm{O}+\right.} \\
\mathrm{H}]^{+}\end{array}$ & 221.18999 & 221.18974 & -1.13 & $\begin{array}{c}203.17982(100), 161.13272(21), 147.11707(45), \\
133.10150(30), 119.08596(81), 109.10172(35), \\
107.08604(35), 95.08617 \text { (56) }\end{array}$ \\
\hline 95 & 46.39 & Trihydroxy-dimethoxyflavone & $\mathrm{C}_{17} \mathrm{H}_{14} \mathrm{O}_{7}$ & {$[\mathrm{M}-\mathrm{H}]^{-}$} & 329.06667 & 329.06699 & 0.97 & ND \\
\hline 96 & 46.12 & CCFFQA-2 & $\mathrm{C}_{45} \mathrm{H}_{40} \mathrm{O}_{18}$ & {$[\mathrm{M}-\mathrm{H}]^{-}$} & 867.21419 & 867.21252 & -1.93 & 161.02298 (44), 135.04358 (17), 133.02797 (15) \\
\hline 97 & 46.55 & 3"-Ethoxyl-(3"R)-pluthiophenol & $\mathrm{C}_{15} \mathrm{H}_{14} \mathrm{O}_{2} \mathrm{~S}$ & {$[\mathrm{M}+\mathrm{H}]^{+}$} & 259.07873 & 259.07944 & 2.74 & $\begin{array}{c}213.03680(100), 199.02121(55), 185.04228(53), \\
173.00558(78)\end{array}$ \\
\hline 98 & 46.57 & 3,4,5-TriCQE & $\mathrm{C}_{36} \mathrm{H}_{34} \mathrm{O}_{15}$ & {$[\mathrm{M}-\mathrm{H}]^{-}$} & 705.18249 & 705.18292 & 0.61 & $\begin{array}{r}543.15044(8), 367.10269(2), 349.09255(4), \\
179.03368(47), 161.02313(100), 135.04359(80)\end{array}$ \\
\hline 99 & 46.82 & (3"R)-pluthiophenol * & $\mathrm{C}_{13} \mathrm{H}_{10} \mathrm{O}_{2} \mathrm{~S}$ & {$[\mathrm{M}+\mathrm{H}]^{+}$} & 231.04743 & 231.04755 & 0.52 & $213.04740(36), 200.02346$ (17), 199.02358 (53) \\
\hline 100 & 46.89 & Clovane-2 $\alpha, 9 \beta$-diol * & $\mathrm{C}_{15} \mathrm{H}_{26} \mathrm{O}_{2}$ & $\frac{\left[\mathrm{M}-\mathrm{H}_{2} \mathrm{O}+\right.}{\mathrm{H}]^{+}}$ & 221.18999 & 221.19037 & 1.72 & $\begin{array}{c}203.17920(100), 161.13242(11), 147.11676(33) \\
121.10132(20), 109.10140(31), 107.08585(31), \\
95.08591(58)\end{array}$ \\
\hline 101 & 47.08 & Casticin * & $\mathrm{C}_{19} \mathrm{H}_{18} \mathrm{O}_{8}$ & {$[\mathrm{M}-\mathrm{H}]^{-}$} & 373.09289 & 373.09366 & 2.06 & $\begin{array}{c}358.06879(77), 343.04517(100), 328.02164(18), \\
312.99838(13), 300.02676(33), 285.00342(34), \\
257.00858(33)\end{array}$ \\
\hline 102 & 47.17 & $(8 R, 9 R)$-Isocaryolane-8,9-diol * & $\mathrm{C}_{15} \mathrm{H}_{26} \mathrm{O}_{2}$ & $\begin{array}{c}{\left[\mathrm{M}-\mathrm{H}_{2} \mathrm{O}+\right.} \\
\mathrm{H}]^{+}\end{array}$ & 221.18999 & 221.18962 & -1.67 & ND \\
\hline 103 & 47.53 & Sesquiterpene & $\mathrm{C}_{15} \mathrm{H}_{26} \mathrm{O}_{2}$ & $\begin{array}{c}{\left[\mathrm{M}-\mathrm{H}_{2} \mathrm{O}+\right.} \\
\mathrm{H}]^{+}\end{array}$ & 221.18999 & 221.18941 & -2.62 & ND \\
\hline 104 & 47.62 & 3"-Ethoxyl-(3"R)-pluthiophenol-4"-acetate & $\mathrm{C}_{17} \mathrm{H}_{16} \mathrm{O}_{3} \mathrm{~S}$ & {$[\mathrm{M}+\mathrm{H}]^{+}$} & 301.08929 & 301.08945 & 0.53 & ND \\
\hline 105 & 47.96 & (3"R)-Pluthiophenol-4"-acetate * & $\mathrm{C}_{15} \mathrm{H}_{12} \mathrm{O}_{3} \mathrm{~S}$ & {$[\mathrm{M}+\mathrm{H}]^{+}$} & 273.05799 & 273.05813 & 0.51 & $231.04753(40), 213.03694(76), 184.03423(100)$ \\
\hline 106 & 48.73 & (3"S)-pluthiophenol & $\mathrm{C}_{13} \mathrm{H}_{10} \mathrm{O}_{2} \mathrm{~S}$ & {$[\mathrm{M}+\mathrm{H}]^{+}$} & 231.04743 & 231.04758 & 0.65 & ND \\
\hline 107 & 49.42 & 3"-Ethoxyl-(3"S)-pluthiophenol * & $\mathrm{C}_{15} \mathrm{H}_{14} \mathrm{O}_{2} \mathrm{~S}$ & {$[\mathrm{M}+\mathrm{H}]^{+}$} & 259.07873 & 259.07918 & 1.74 & $\begin{array}{c}213.03680(100), 199.02121(42), 185.04228(43), \\
173.00558(73)\end{array}$ \\
\hline 108 & 49.62 & Sesquiterpene & $\mathrm{C}_{15} \mathrm{H}_{26} \mathrm{O}_{2}$ & $\begin{array}{c}{\left[\mathrm{M}-\mathrm{H}_{2} \mathrm{O}+\right.} \\
\mathrm{H}]^{+}\end{array}$ & 221.18999 & 221.18947 & -2.35 & 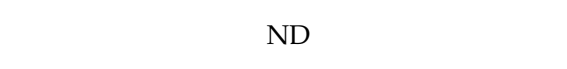 \\
\hline 109 & 53.00 & Dibutylphthalate * & $\mathrm{C}_{16} \mathrm{H}_{22} \mathrm{O}_{4}$ & {$[\mathrm{M}-\mathrm{H}]^{-}$} & 277.15899 & 277.15901 & 0.07 & ND \\
\hline 110 & 53.13 & (3"S)-Pluthiophenol-4"-acetate & $\mathrm{C}_{15} \mathrm{H}_{12} \mathrm{O}_{3} \mathrm{~S}$ & {$[\mathrm{M}+\mathrm{H}]^{+}$} & 273.05799 & 273.05838 & 1.43 & 231.04761 (40), 213.03699 (75), 184.03421 (100) \\
\hline 111 & 53.28 & 3"-Ethoxyl-(3"S)-pluthiophenol-4"-acetate * & $\mathrm{C}_{17} \mathrm{H}_{16} \mathrm{O}_{3} \mathrm{~S}$ & {$[\mathrm{M}+\mathrm{H}]^{+}$} & 301.08929 & 301.08917 & -0.40 & $\begin{array}{c}213.03697(100), 185.04243(45), 184.03429(48), \\
173.00571(8)\end{array}$ \\
\hline 112 & 54.98 & trans-Coniferyl aldehyde * & $\mathrm{C}_{10} \mathrm{H}_{10} \mathrm{O}_{3}$ & {$[\mathrm{M}+\mathrm{H}]^{+}$} & 179.07027 & 179.07063 & 2.01 & ND \\
\hline 113 & 55.18 & (+)-9'-isovaleryllariciresinol * & $\mathrm{C}_{25} \mathrm{H}_{32} \mathrm{O}_{7}$ & {$[\mathrm{M}-\mathrm{H}]^{-}$} & 443.20753 & 443.20905 & 3.43 & ND \\
\hline 114 & 55.94 & Stigmasterol * & $\mathrm{C}_{29} \mathrm{H}_{48} \mathrm{O}$ & {$[\mathrm{M}-\mathrm{H}]^{-}$} & 411.36324 & 411.36307 & -0.41 & ND \\
\hline
\end{tabular}

* The compounds unambiguously identified with the reference standards comparison; CoQA: coumaroyl quinic acid; CQA: caffeoyl quinic acid; CQE: ethyl caffeoyl quinate; CQM: methyl caffeoyl quinate; CFQM: methyl caffeoyl-ferulyl-quinate; CCFQA: dicaffeoyl-ferulyl-quinic acid; CCCFQA: tricaffeoyl-ferulyl-quinic acid; CCFFQA: dicaffeoyl-diferulyl-quinic acid; FQA: feruloyl quinic acid; TQA: 3,4,5-trihydroxycinnamoyl quinic acid. Although the compounds 33, 43, 44, 56, 59, 85, 102, 109, and 112-114 were identified by the comparison of $t_{\mathrm{R}}$ with reference standards, while the contents of them were too low to detect their fragments ions, thus they were stated as ND. 


\subsubsection{Structural Elucidation of Phenolic Acids}

Peaks 5, 6, 10, 13, 14, 19, 23, 33, 34, 52, 59, 74, 81, 109, 112, and 113 were accurately identified by comparison with reference standards (Table 1, Figure S2).

Peaks 1 and 7 were unambiguously identified as 3,4-dihydroxy benzoic acid and 3,4-dihydroxybenzaldehyde by comparison with reference standards isolated from P. indica [7], respectively. Figure 4 showed the MS/MS fragmentation pattern of benzoic acid (peak 1) and benzaldehyde (peak 7): the alpha bond cleavage of carbonyl was susceptible to occur in benzoic acid and benzaldehyde, and then generated a fragment ion peak at $\mathrm{m} / \mathrm{z} 109.02793$ and 109.02798 by removing $44 \mathrm{Da}$ and $28 \mathrm{Da}$, respectively. Thus, the two types of compounds could be distinguished by the mass lost during this process (Figure S20). Peak 12 was definitely identified as 3-methoxy-4-hydroxybenzoic acid by comparison with reference standard. Besides the rule mentioned above, it was also prone to remove one methyl radical, resulting in a strong fragment ion peak at $\mathrm{m} / \mathrm{z} 152.01041\left[\mathrm{M}-\mathrm{H}-\mathrm{CH}_{3}\right]^{-}$; at the same time, it could remove one $\mathrm{CO}_{2}$ to form a fragment ion peak of $m / z 123.04406\left[\mathrm{M}-\mathrm{H}-\mathrm{CO}_{2}\right]^{-}$. Continually, it could remove one $\mathrm{CO}_{2}$ or methyl radical to form fragment ion peak of $\mathrm{m} / \mathrm{z} 108.02058$ $\left[\mathrm{M}-\mathrm{H}-\mathrm{CH}_{3}-\mathrm{CO}_{2}\right]^{-} /\left[\mathrm{M}-\mathrm{H}-\mathrm{CO}_{2}-\mathrm{CH}_{3}\right]^{-}$, respectively (Figure 4 and Figure S20).

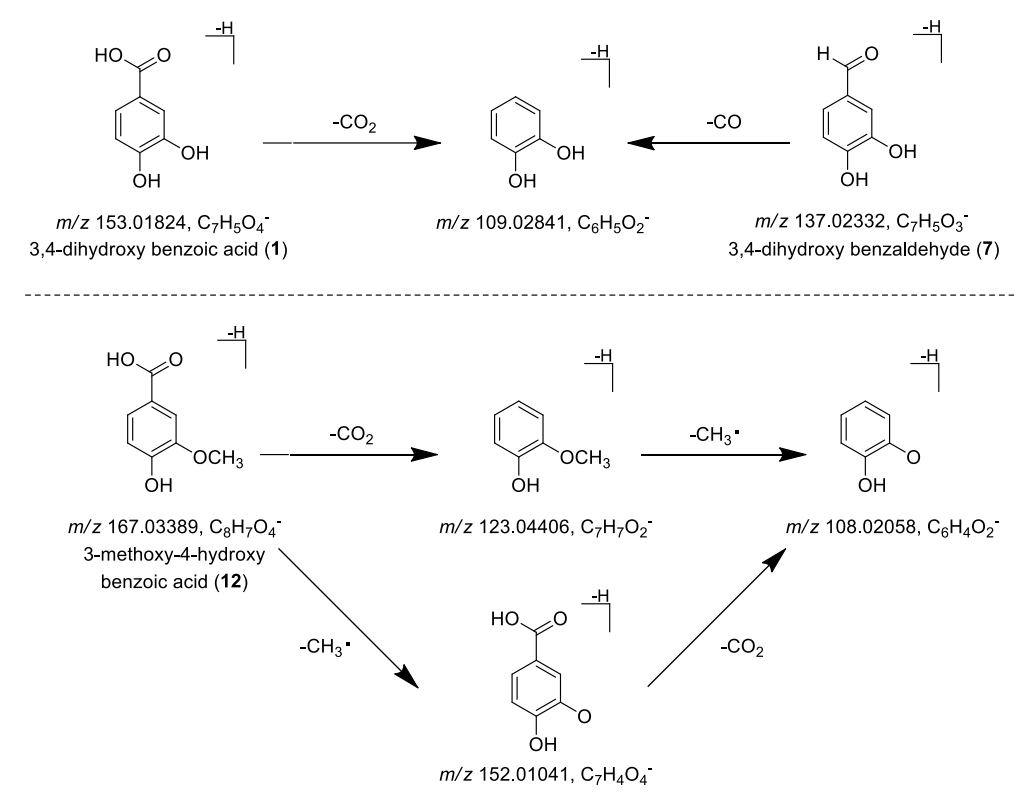

Figure 4. Proposed fragmentation patterns and characteristic ions of 3,4-dihydroxy benzoic acid (1), 3,4-dihydroxy benzaldehyde (7) and 3-methoxy-4-hydroxy benzoic acid (12).

Peak $8\left(\mathrm{~m} / 2\right.$ 167.03381 $\left.[\mathrm{M}-\mathrm{H}]^{-}\right)$(Figure S21), which has the molecular ion $\mathrm{C}_{8} \mathrm{H}_{7} \mathrm{O}_{4}{ }^{-}$in its MS/MS spectrum, had fragment ion peaks of $m / z 152.01022\left[\mathrm{M}-\mathrm{H}-\mathrm{CH}_{3}\right]^{-}$and $108.02016\left[\mathrm{M}-\mathrm{H}-\mathrm{CH}_{3}-\right.$ $\left.\mathrm{CO}_{2}\right]^{-}$, suggesting that one methyl radical $(15 \mathrm{Da})$ and $\mathrm{CO}_{2}(44 \mathrm{Da})$ were cleaved from the structure. The existence of 3,4-dihydroxybenzoic acid (1) in this plant has been proved above, combining the biosynthetic pathway, peak 8 was tentatively presumed to be methyl 3,4-dihydroxybenzoate.

In the MS/MS spectrum of peak $17\left(\mathrm{~m} / \mathrm{z} 137.02303, \mathrm{C}_{7} \mathrm{H}_{5} \mathrm{O}_{3}{ }^{-}\right.$) (Figure $\left.\mathrm{S} 21\right)$, one $\mathrm{CO}_{2}$ (44 Da) was cleaved according to the base peak ion of $m / z 93.03311\left[\mathrm{M}-\mathrm{H}-\mathrm{CO}_{2}\right]^{-}$. Therefore, it was deduced that there was a carboxyl group directly attached to the benzene ring in the structure. As a result, peak $\mathbf{1 7}$ was tentatively speculated to be 2-hydroxybenzoic acid or 3-hydroxybenzoic acid combining with its molecular formula.

\subsubsection{Structural Elucidation of Thiophenes}

As mentioned above, four thiophenes: (3"R)-pluthiophenol (peak 99, $\mathrm{m} / \mathrm{z} 231.04743, t_{\mathrm{R}} 46.82 \mathrm{~min}$ ), (3"R)-pluthiophenol-4"-acetate (peak 105, $\mathrm{m} / \mathrm{z} 273.05813, t_{\mathrm{R}} 47.94 \mathrm{~min}$ ), 3"-ethoxyl-(3"S)-pluthiophenol 
(peak 107, $\mathrm{m} / \mathrm{z} 259.07918, t_{\mathrm{R}} 49.42 \mathrm{~min}$ ), and 3"-ethoxyl-(3"S)-pluthiophenol-4"-acetate (peak 111, $\mathrm{m} / \mathrm{z}$ $301.08917, t_{\mathrm{R}} 53.25 \mathrm{~min}$ ) have been isolated and identified in our lab [7]. When extracting the above ions from PIE2, four pairs of ion peaks were obtained, the four peaks unseparated were presumed to be (3"S)-pluthiophenol (peak 106, $\mathrm{m} / \mathrm{z} 231.04743, t_{\mathrm{R}} 48.73 \mathrm{~min}$ ), (3"S)-pluthiophenol-4"-acetate (peak 110, $\mathrm{m} / \mathrm{z}$ 273.05813, $t_{\mathrm{R}} 53.13 \mathrm{~min}$ ), 3"-ethoxyl-(3"R)-pluthiophenol (peak 97, $\mathrm{m} / \mathrm{z} 259.07918, t_{\mathrm{R}}$ $46.55 \mathrm{~min}$ ) and 3"-ethoxyl-(3"R)-pluthiophenol-4"-acetate (peak 104, $\mathrm{m} / \mathrm{z} 301.08917, t_{\mathrm{R}} 47.62 \mathrm{~min}$ ) (Figure 5). In addition, the fragmentation ions of peaks 110 and 97 were similar to those of peaks 105 and 107 (Table 1), respectively, which preliminary confirmed the above inference. While the MS/MS fragmentation ions of peaks $\mathbf{1 0 4}$ and $\mathbf{1 0 6}$ have not been detected. Summarizing their chromatographic elution order, it was found that in the $\mathrm{CH}_{3} \mathrm{CN}-\mathrm{H}_{2} \mathrm{O}$ system the $t_{\mathrm{R}}$ of the thiophenes with the same planar structure was related to the configuration: the $t_{\mathrm{R}}$ of 3 " $R$-thiophene was shorter than that of 3"S-thiophene. The four thiophenes peaks $97,104,106$, and 110 could be tentatively identified due to their peak orders, and all of them were possible new compounds.

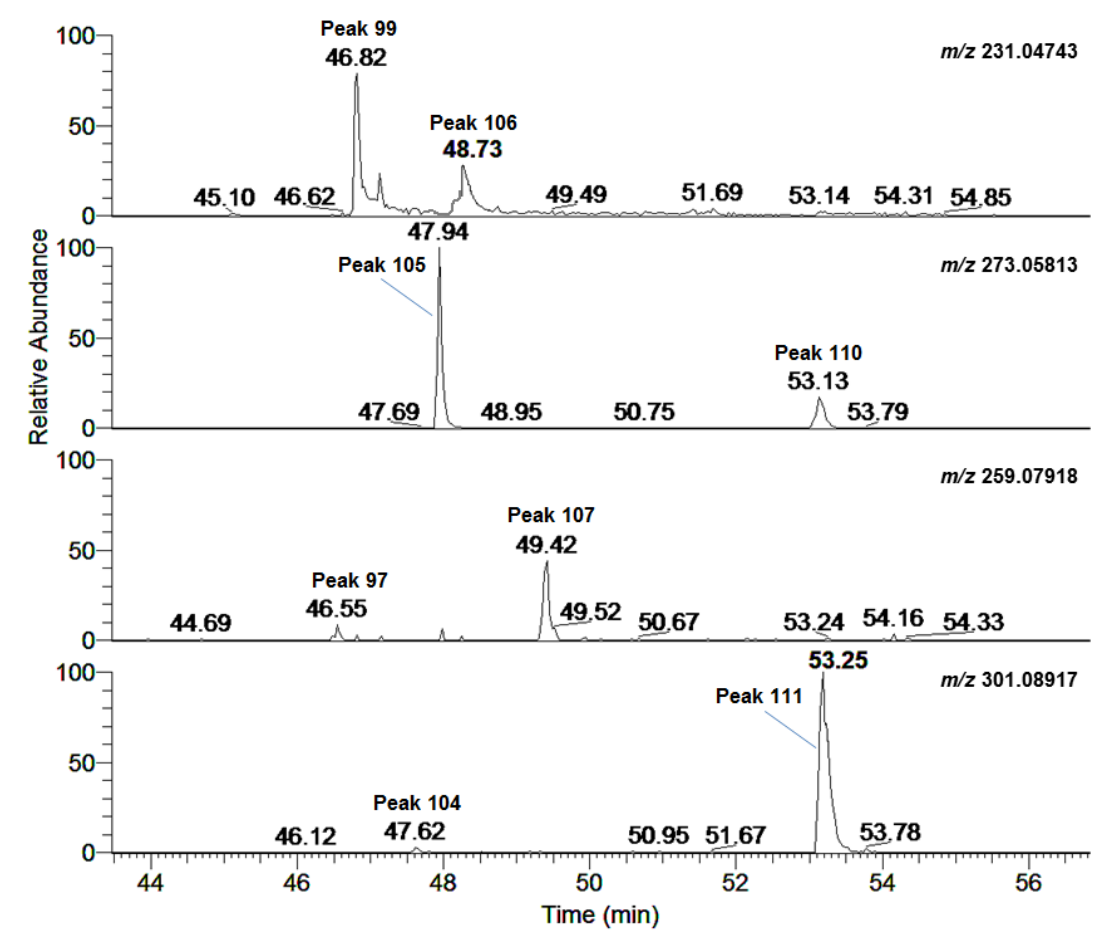

Figure 5. EIC from PIE2 A: EIC of $m / z$ 231.04743; B: EIC of $m / z$ 273.05813; C: EIC of $m / z 259.07918$; D: EIC of $m / z$ 301.08917.

\subsubsection{Structural Elucidation of Other Compounds}

In addition, 13 flavonoids (Figure S4) and 11 other compounds (Figure S5) were unambiguously identified by comparison to reference standards obtained and identified by our lab $[7,8]$ (Table 1$)$. At the same time, when taking literatures into consideration, the possible structures of 11 compounds (9 flavonoids and two sesquiterpenes) were tentatively predicted (Table 1).

During this process, an interesting phenomenon has been found that when the 1-position carboxyl of quinic acids were methylated, the base peak of the MS/MS spectra of CQMs were not 191.05501 [quinic acid $-\mathrm{H}]^{-}$or 173.04445 [quinic acid $\left.-\mathrm{H}-\mathrm{H}_{2} \mathrm{O}\right]^{-}$any more, they became 161.02332 [caffeoyl $\left.\mathrm{H}_{2} \mathrm{O}-\mathrm{H}\right]^{-}$or 135.04406 [caffeoyl $\left.-\mathrm{CO}_{2}-\mathrm{H}\right]^{-}$. We tried to explain the reason as following: when the quinic acid compound was ionized, the protons at the 1-carboxyl were easily lost, forming a negative charge center. When the charge migrated to the binding oxygen atom between the quinic acid nucleus and the substituted caffeoyl group, the cleavage could occur, and $\mathrm{m} / \mathrm{z} 191.05501$ [quinic acid $-\mathrm{H}]^{-}$and 173.04445 [quinic acid $\left.-\mathrm{H}-\mathrm{H}_{2} \mathrm{O}\right]^{-}$appeared. While when the 1-carboxyl was methylated, the negative 
charge center will be generated on the hydroxyl group of the substituted caffeoyl group, and after electron transferred, the chemical bond between the substituted caffeoyl group and the quinic acid nucleus would be broken, and a characteristic ion formed by substituted caffeoyl group would strongly occur on the MS/MS spectrum.

\section{Conclusion}

In summary, a method integrating normal-phase chromatography and reverse-phase chromatography/mass spectrometry analysis was established to accomplish the chemical profiling of PI. According to the retention time $\left(t_{R}\right)$ and the exact mass-to-charge ratio $(\mathrm{m} / \mathrm{z}), 114$ compounds were identified or tentatively identified. Among them, 67 compounds were unambiguously identified by comparing to the standard references. Meanwhile, the rules of MS/MS fragmentation pattern and chromatographic elution order have been generalized by using the reference standard, 47 compounds were tentatively speculated, and 10 of them (peaks 3, 9, 15, 28, 92, 97, 98, 104, 106, and 110) are potentially novel. An accurate and comprehensive chemical composition profiling of the aerial part of the $P$. indica was realized, which laid a foundation for the quality evaluation of the plant.

Supplementary Materials: Supplementary data (the structures of standard references and MS/MS spectrum of the $[\mathrm{M}-\mathrm{H}]^{-}$ions for all peaks) associated with this article can be found in the online version.

Author Contributions: Y.Z. and T.W. designed the research; J.R. and J.Y. performed the experimental work and wrote the manuscript; D.Z., F.S., and J.W. corrected the data and reviewed literatures, L.H. perfected the language. All authors discussed, edited, and approved the final version.

Funding: This work was financially supported by grants from the National Natural Science Foundation of China (81673688) and the Important Drug Development Fund, Ministry of Science and Technology of China (2018ZX09711001-009-010).

Conflicts of Interest: The authors declare no conflicts of interest.

\section{Abbreviations}

$\begin{array}{ll}\text { Acronym } & \text { Full name } \\ \mathrm{CHCl}_{3} & \text { Chloroform } \\ \text { CQA } & \text { Caffeoylquinic acid } \\ \text { CQE } & \text { Ethyl caffeoylquinic acid } \\ \text { CQM } & \text { Methyl caffeoylquinic acid } \\ \text { CoQA } & \text { Coumaroyl quinic acid } \\ \text { CFQM } & \text { Methyl caffeoyl-ferulyl-quinate } \\ \text { CCFQA } & \text { Dicaffeoyl-ferulyl-quinic acid } \\ \text { CCCFQA } & \text { Tricaffeoyl-ferulyl-quinic acid } \\ \text { CCFFQA } & \text { Dicaffeoyl-diferulyl-quinic acid } \\ \text { diCQA } & \text { Dicaffeoylquinic acid } \\ \text { diCQE } & \text { Ethyl diCaffeoylquinic acid } \\ \text { diCQM } & \text { Methyl dicaffeoylquinic acid } \\ \text { EtOH } & \text { Ethanol } \\ \text { FQA } & \text { Feruloyl quinic acid } \\ \text { FEMA } & \text { Flavor and Extract Manufacturers Association } \\ \text { GRAS } & \text { Generally recognized as safe } \\ \text { LC-MS/MS } & \text { Liquid chromatograph-mass/mass spectrometry } \\ \text { MeOH } & \text { Methanol } \\ \text { OC-MS } & \text { Orthogonal chromatography-mass spectrometry } \\ \text { PI } & \text { P. indica 70\% EtOH extract } \\ \text { PIEs } & \text { Silica gel fractionation of } 95 \% \text { EtOH eluate of } P \text {. indica } \\ \text { TQA } & 3,4,5 \text {-Trihydroxycinnamoyl quinic acid } \\ \text { triCQA } & \text { Tricaffeoylquinic acid } \\ \text { triCQE } & \text { Ethyl tricaffeoyl quinate } \\ \text { triCQM } & \text { Methyl tricaffeoylquinic acid } \\ & \end{array}$




\section{References}

1. Zhou, J.S.; Wang, F.G.; Xing, F.W. Pluchea sagitallis, a naturalized medical plant in mainland China. Guangxi Zhiwu 2010, 30, 455-457.

2. Buranasukhon, W.; Athikomkulchai, S.; Tadtong, S.; Chittasupho, C. Wound healing activity of Pluchea indica leaf extract in oral mucosal cell line and oral spray formulation containing nanoparticles of the extract. Pharm. Biol. 2017, 55, 1767-1774. [CrossRef] [PubMed]

3. Zhang, Z.Q.; Cheng, Y.Q. Flora of China; Beijing Science Press: Beijing, China, 1979; Volume 75, pp. 50-54.

4. Nazri, N.A.A.M.; Ahmat, N.; Adnan, A.; Mohamad, S.A.S.; Ruzaina, S.A.S. In vitro antibacterial and radical scavenging activities of Malaysian table salad. Afr. J. Biotechnol. 2011, 10, 5728-5735.

5. Sirichaiwetchakoon, K.; Lowe, G.M.; Thumanu, K.; Eumkeb, G. The effect of Pluchea indica (L.) Less. tea on adipogenesis in 3T3-L1 adipocytes and lipase activity. Evid. Based Complement. Altern. Med. 2018, 2018, 4108787. [CrossRef] [PubMed]

6. Hussain, H.; Al-Harrasi, A.; Abbas, G.; Rehman, N.U.; Mabood, F.; Ahmed, I. The genus Pluchea: Phytochemistry, traditional uses, and biological activities. Chem. Biodiver. 2013, 10, 1944-1971. [CrossRef]

7. Ruan, J.Y.; Li, Z.; Yan, J.J.; Huang, P.J.; Yu, H.Y.; Han, L.F.; Zhang, Y.; Wang, T. Bioactive constituents from the aerial parts of Pluchea indica Less. Molecules 2018, 23, 2104. [CrossRef] [PubMed]

8. Ruan, J.Y.; Xu, Y.P.; Qu, L.; Wang, T.; Yu, H.Y.; Zhang, Y. Isolation and indentifition of flavonoids from aerial part of Pluchea indica Less. Shenyang Yaoke Daxue Xuebao 2018, 35, 607-610.

9. Naveed, M.; Hejazi, V.; Abbas, M.; Kamboh, A.A.; Khan, G.J.; Shumzaid, M. Chlorogenic acid (CGA): A pharmacological review and call for further research. Biomed. Pharmcother. 2018, 97, 67-74. [CrossRef]

10. Rahman, H.A.; Saari, N.; Abas, F.; Ismail, A.; Mumtaz, M.W.; Hamid, A.A. Anti-obesity and antioxidant activities of selected medicinal plants and phytochemical profiling of bioactive compounds. Int. J. Food Prop. 2017, 20, 2616-2629. [CrossRef]

11. Cohen, S.M.; Fukushima, S.; Gooderham, N.J.; Guengerich, F.P.; Hecht, S.S.; Rietjens, I.M. Safety evaluation of substituted thiophenes used as flavoring ingredients. Food Chem. Toxicol. 2017, 99, 40-59. [CrossRef]

12. Godos, J.; Castellano, S.; Ray, S.; Grosso, G.; Galvano, F. Dietary polyphenol intake and depression: Results from the mediterranean healthy eating, lifestyle and aging (meal) study. Molecules 2018, 23, E999. [CrossRef] [PubMed]

13. Jaiswal, R.; Müller, H.; Müller, A.; Karar, M.G.; Kuhnert, N. Identification and characterization of chlorogenic acids, chlorogenic acid glycosides and flavonoids from Lonicera henryi L. (Caprifoliaceae) leaves by LC-MS ${ }^{\text {. }}$ Phytochemistry 2014, 108, 252-263. [CrossRef] [PubMed]

14. Wang, C.; Zhang, X.; Yan, X.; Ye, W.; Ma, S.; Jiang, Y. Chemical profiling of Euphorbia fischeriana Steud. by UHPLC-Q/TOF-MS. J. Pharm. Biomed. Anal. 2017, 151, 126-132. [CrossRef] [PubMed]

15. Yang, W.Z.; Ye, M.; Qiao, X.; Liu, C.F.; Miao, W.J.; Bo, T.; Tao, H.Y.; Guo, D.A. A strategy for efficient discovery of new natural compounds by integrating orthogonal column chromatography and liquid chromatography/mass spectrometry analysis: Its application in Panax ginseng, Panax quinquefolium and Panax notoginseng to characterize 437 potential new ginsenosides. Anal. Chim. Acta 2012, 20, 56-66.

16. Xu, L.L.; Lin, Z.L. Separation of acidic aromatic compounds and emodin-bonded silica gel chromatographic column by HPLC. J. Anal. Sci. 2015, 31, 183-187.

17. Qu, L.; Ruan, J.Y.; Jin, L.J.; Shi, W.Z.; Li, X.X.; Han, L.F.; Zhang, Y.; Wang, T. Xanthine oxidase inhibitory effects of the constituents of Chrysanthemum morifolium stems. Phytochem. Lett. 2017, 19, 39-45. [CrossRef]

18. Qu, L.; Bu, S.Y.; Li, J.L.; Han, L.F.; Wang, T.; Zhang, Y. Identification of compounds isolated from the stems of Chrysanthemum morifolium Ramat. Qiju. Shenyang Yaoke Daxue Xuebao 2016, 33, 525-530.

19. Lee, S.; Oh, D.G.; Lee, S.; Kim, G.R.; Lee, J.S.; Son, Y.K.; Bae, C.H.; Yeo, J.; Lee, C.H. Chemotaxonomic metabolite profiling of 62 indigenous plant species and its correlation with bioactivities. Molecules 2015, 20, 19719-19734. [CrossRef]

20. Schmeda-Hirschmann, G.; Quispe, C.; Gonzalez, B. Phenolic profiling of the south American "baylahuen" tea (Haplopappus spp., Asteraceae) by HPLC-DAD-ESI-MS. Molecules 2015, 20, 913-928. [CrossRef]

21. Jaiswal, R.; Deshpande, S.; Kuhnert, N. Profiling the chlorogenic acids of Rudbeckia hirta, Helianthus

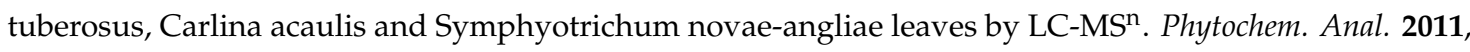
22, 432-441. [CrossRef] 
22. Che, Y.; Wang, Z.; Zhu, Z.; Ma, Y.; Zhang, Y.; Gu, W.; Zhang, J.; Rao, G. Simultaneous qualitation and quantitation of chlorogenic acids in Kuding Tea using ultra-high-performance liquid chromatography-diode array detection coupled with linear ion trap-orbitrap mass spectrometer. Molecules 2016, 21, 1728. [CrossRef]

23. Zhang, S.H.; Hu, X.; Shi, S.Y.; Huang, L.Q.; Chen, W.; Chen, L.; Cai, P. Typical ultraviolet spectra in combination with diagnostic mass fragmentation analysis for the rapid and comprehensive profiling of chlorogenic acids in the buds of Lonicera macranthoides. Anal. Bioanal. Chem. 2016, 408, 3659-3672. [CrossRef]

Sample Availability: Samples of the compounds 1, 2, 4, 5-7, 10-14, 16, 19, 23, 29, 31-35, 37-40, 42-45, 47, 51-57, $59,61,65,66,68,71,73-77,81,83,85,86,89,91,93,94,99-102,105,107,109,111-114$ are available from the authors.

(C) 2019 by the authors. Licensee MDPI, Basel, Switzerland. This article is an open access article distributed under the terms and conditions of the Creative Commons Attribution (CC BY) license (http://creativecommons.org/licenses/by/4.0/). 